\title{
A holistic approach to development of diets for Ballan wrasse (Labrus berggylta) - a new species in aquaculture
}

Wild wrasses are used for delousing of farmed salmon but increasing demands have prompted the salmon industry to develop culture of Ballan wrasse. One of the bottlenecks has been nutrition and feed intake in the juvenile phase, while broodstock nutrition is considered critical for production of viable offspring. The present study was aimed at developing functioning ongrowing and broodstock diets for Ballan wrasse. In juveniles the best lengthwise growth was identified at $65 \%$ dietary protein, $12 \%$ lipid and $16 \%$ carbohydrate. To investigate if the requirements for the other nutrients were covered by the diets developed for the species, the nutrient composition in juveniles (whole body) and broodstock (female gonad) were analyzed and compared to the composition in wild fish. We found that the levels of the lipid soluble vitamins A, K and D were lower in cultured than in wild fish, however, the requirements for these nutrients in Ballan wrasse are not known. Other candidate nutrients for more in-depth investigation are the bone minerals, zinc, taurine and fatty acid composition. 
Kristin Hamre, National Institute of Nutrition and Seafood Research (NIFES), PO Box 2029, NO-5817 Bergen, Norway

Andreas Nordgreen, Nofima AS, Kjerreidviken 16, NO-5141 Fyllingsdalen, Norway. Present address: Norsildmel AS, Kjerreidviken 16, NO-5141 Fyllingsdalen, Norway

Olav Breck, Marine Harvest Labrus, Sandviksboder 78a, NO-5835 Bergen

Espen Grøtan, Marine Harvest Labrus, Sandviksboder 78a, NO-5835 Bergen

*Corresponding author

E-mail: kha@nifes.no

Telephone: +4748185034

Fax: +4755905299 


\section{Introduction}

Salmon lice are currently a major environmental and economic issue in the salmon industry (Bjørn et al. 2012). In some geographical regions, lice have developed resistance to commonly used medications (Horsberg 2000), which has led to more frequent delousing and an associated increase in treatment costs. The medications used may pose an environmental threat, since some bio-accumulate in the environment and are toxic to wild fauna such as non target crustaceans near the aquaculture sites (Horsberg 2000). In addition, increased levels of lice on farmed salmon can increase the burden of salmon lice on wild salmonids (Bjørn et al. 2012).

An environmental friendly treatment alternative is biological delousing of salmon with cleaner fish. Wild caught wrasse have been used for delousing salmon for at least two decades (Kvenseth 2011), but the increasing incidence of drug resistant salmon lice has increased the demand for cleaner fish to such an extent that questions have been raised concerning wild catch posing a negative effect on the ecosystems (Mortensen \& Karlsbakk 2012). This is the background for the recent efforts to farm Ballan wrasse (Labrus bergylta).

Commercial juvenile production of Ballan wrasse was established using knowledge and infrastructure from Atlantic cod (Gadus morhua) farming and showed some success within two years, however numbers are still low and there are many technical and biological challenges. One problem was that fish transferred to weaning and grow-out diets had slow growth and high mortalities (Espen Grøtan, pers comm). One reason for this was later shown to be the absence of attractants in the commercial diets used. Addition of shrimp meal to the diets increased feed intake and improved rearing results to an extent (Nordgreen et al., unpublished; Opstad et al. unpublished). Furthermore it was hypothesized that commercial fish diets developed for other species such as Atlantic cod may be inappropriate for Ballan wrasse. For instance Ballan wrasse is a stomachless fish with an intestine length of only 2/3 of it's body length (Hamre \& Sæle 2011), and it's feeding habits and natural prey selection PeerJ reviewing PDF | (v2013:05:466:2:0:NEW 17 Jun 2013) 
suggest a nutrient requirements and digestive capacity that differs from other commercial marine fish species. Ballan wrasse feed on invertebrates, with species in the classes Gastropoda, Decapoda, Echinodermata and Bivalvia being the most abundant feed items in intestines from wild fish caught at Azores, in the North Atlantic Ocean (Figueiredo et al. 2005). This is similar to the feed selection among other wrasse species according to Lek et al. (2011) and indicates that the natural diet of Ballan wrasse is relatively low in lipid and easily digestible.

The present study is a first approach to screen for nutrient requirements of Ballan wrasse in order to facilitate it's domestication. Optimal macronutrient compositions were studied using a three component mixture design, where protein, lipid and carbohydrate were varied systematically within the requirement ranges found for fish in general. Based on previous experience, the results from the macronutrient experiment, and assumptions regarding protein and lipid sources and micronutrient supplementation, a new diet (Labrus, Skretting AS) was formulated for use in the commercial production of wrasse. The whole body nutrient composition of fish groups fed the Labrus Skretting diet, or a moist diet based on Skretting Vitalis (a commercial broodstock diet) blended with shrimp, for at least three months was compared with the whole body nutrient composition of wild fish. A similar approach was used for broodstock that had been fed the moist diet (Vitalis, Skretting AS blended with shrimp) for one year. Female gonads from these fish were analyzed and compared with female gonads from wild fish. Both groups of fish were sampled just before spawning. Assuming that the dietary intake of wild fish fulfills their nutrient requirements and this is reflected in organ nutrient status, large differences in nutrient composition between wild and cultured fish were interpreted as nutritional imbalances in the cultured fish. 


\section{Materials and methods}

This study was carried out within the Norwegian animal welfare act guidelines (code 750.000), at Marine Harvest Labrus. As the fish trials were assumed to be nutrition trials based on all available studies up to the date of the trial, no specific permit was required under the guidelines.

\section{Diets}

The diets for the macronutrient study were produced by NOFIMA. All dry ingredients for each diet were weighed and carefully mixed to a homogenous blend. Fresh, bone free cod fillets (Gadus morhua) were blended in a standard food processor. The oil, dry ingredients and ethoxiquin (calculated to $25 \mathrm{mg} / \mathrm{kg}$ on dry weight basis) were then added while mixing to create a homogenous blend. Diet formulations and analyzed macronutrient compositions are given in table 1 . The feed dough of each diet was fed with a manual press, into plastic sausage casings with a diameter of $2 \mathrm{~cm}$. The sausages were heat treated for 12 minutes at $83{ }^{\circ} \mathrm{C}$ with 100\% humidity in a convection oven (SCC 202, Rational AG, Landsberg am Lech, Germany) to denature the protein. After cooling, the plastic casing was removed and the heat denaturated diets were dried for approximately $24 \mathrm{~h}$ at $40{ }^{\circ} \mathrm{C}$ in a shelf dryer. The water contents of the different diets were analyzed with a Mettler Toledo HG53 Moisture Analyzer during drying to ensure the water content in each diet was similar. Diets were then ground (As200 Basic, Retsch, Düsseldorf, Germany) and sieved to obtain the required particle sizes. Homogenous sample of all diets were analyzed for crude protein (Nx6.25), ash, lipid (Bligh and Dyer) and water content. Diet carbohydrate concentrations were estimated based on subtraction. The feed was packed in closed plastic bags and stored at $4{ }^{\circ} \mathrm{C}$ until feeding.

The analyzed nutrient compositions of the commercial diets, Labrus and Vitalis (Skretting, Stavanger, Norway), and the moist diet made from Vitalis and shrimp are given in Table 2. 
The moist diet was made by crushing $100 \mathrm{~kg}$ Vitalis cal (Skretting) and mixing in $40 \mathrm{~kg}$ boiled, frozen/thawed and minced Greenland shrimp (local supplier), $4.8 \mathrm{~kg}$ wheat gluten for binding and $22 \mathrm{~L}$ fresh water. The dough was then pelleted in a pelleting machine.

\section{Fish and sampling}

Fish for the study on macronutrient composition were obtained from the production line at Marine Harvest Labrus AS (MHL). The initial weight was 1.27 $\pm 0.19 \mathrm{~g}$, total length $4.53 \pm 0.21 \mathrm{~cm}$ and condition factor $1.36 \pm 0.10$ (mean $\pm S D, n=47)$. The fish were held in $100 \mathrm{~L}$ tanks, at 50 fish per tank, with flow-through water $\left(3 \mathrm{~L} \mathrm{~min}^{-1}\right)$, pumped from $150 \mathrm{~m}$ depth and heated to $16{ }^{\circ} \mathrm{C}$. Oxygen concentration was $7.5-8.0 \mathrm{mg} \mathrm{L}^{-1}$. The light regime was continuous light from fluorescent lamps placed above the tanks. The fish were fed continuously, using belt feeders at 7 - $10 \mathrm{~g}$ feed per tank per day. At the end of the study, the total length and weight of the fish were measured, 6 fish per tank were pooled for analyses of whole body macronutrient composition while livers from 25 fish per tank were dissected out, pooled and analyzed for macronutrient composition.

Three groups of cultured juvenile fish (mean weight 3-13g, Table 6) were sampled for analyses of whole body nutritional composition from the production line of MHL. The fish were held in $25 \mathrm{~m}^{3}$ tanks with continuous fluorescent light, temperature $12-14{ }^{\circ} \mathrm{C}$, Oxygen 7.5 - 8.0 $\mathrm{mg} \mathrm{L}^{-1}$ and had been fed the diets listed in Table 3 for more than three months. Wild fish (430 \pm 138 g, mean $\pm S D, n=10$, Table 6) were caught in August 2011 in fish traps near Austevoll Aquaculture Research Station which is situated near Bergen in Western Norway. The size of the wild fish enabled analyses of all nutrients in individual fish, but the size difference between wild and cultured fish was not optimal. However, it was not feasible to obtain wild fish in the size range of the available cultured fish within the time and resource limits of the project. Samples of 30-50 pooled cultured fish or individual wild fish were killed with an overdose of MS222, immersed in fresh water, frozen on dry ice or at $-80^{\circ} \mathrm{C}$, 
transferred to NIFES on dry ice, thawed and homogenized using a kitchen blender. Sample portions were frozen and stored at $-80^{\circ} \mathrm{C}$ for future analyses of all analytes except minerals. Samples for analysis of minerals were freeze dried and further homogenized by grinding on a Retsch Mill (Retsch Gmbh, Haan, Germany).

Captive broodstock (718 $\pm 91 \mathrm{~g}$, mean $\pm \mathrm{SD}, \mathrm{n}=14$ ) for analyses of the nutrient composition of female gonad were also sampled from the production line of MHL. The fish had been held in $40 \mathrm{~m}^{3}$ tanks at a density of $5 \mathrm{~kg} \mathrm{~m}^{3}$ for more than one year and fed the moist diet consisting of 75\% Vitalis (Skretting AS, Stavanger, Norway) and 25\% shrimp. Water temperature was 8 $10{ }^{\circ} \mathrm{C}$, oxygen $7.5-8.0 \mathrm{mg} \mathrm{L}^{-1}$, the light regime was set for delayed spawning and the tanks contained shelters made of plastic sheets where the fish could hide. The fish were scheduled to spawn in December and were sampled on the 14.12.11. The wild fish (521 $\pm 155 \mathrm{~g}$, mean $\pm S D, n=17$ ) were obtained from a local fisherman and moved to MHL, where they were held for less than 1 week without feeding and sampled on the 5.05.10. The spawning season for Ballan wrasse in the wild lasts from May until July. If the gonad from one fish was too small to give material to all the analyses in a series, gonad from two fish were sampled for that series. The fish were killed by a blow to the head, then weight, total length, gonad weight and liver weight were measured (Table 7), the gonad was homogenized in a kitchen blender and portions of sample were distributed to tubes for the different analyses. The samples were immediately frozen on dry ice and transported to NIFES, where they were stored at $-80^{\circ} \mathrm{C}$ until analyses.

\section{Experimental design of the macronutrient study}

The macronutrient experiment was conducted with a three-component mixture design (Cornell 1990). This design allows a variation of protein, lipid and carbohydrate simultaneously, continuously and systematically, within given limits. Using 13 different diets 
(i.e. treatments), of which 12 diets were administered to fish in single tanks, it was possible to cover a wide range of nutrient compositions (Table 1b). One diet (the centre point treatment) was fed to fish in 3 tanks to obtain a measure of tank variation. The experiment lasted for 56 days.

\section{Analytical methods}

The nutrient composition of fish and diets were measured by routine methods established at NIFES. Table 3 gives an overview over the methods with references.

\section{Calculations and statistics}

Data are given as mean $\pm \mathrm{SD}$ and differences and effects were considered significant at $\mathrm{p}<0.05$. Models describing the effects of macronutrient composition on weight, length, condition factor and nutrient composition of whole body were calculated using the software Design Expert ver. 8.0.4. (Stat-Ease Inc. MN, USA). Different models were fitted to the data and the recommended model with the best fit was chosen. Insignificant terms were removed when allowed by hierarchy rules.

Data on micronutrient composition of wrasse female gonad and juvenile whole body were analyzed using Statistica ver. 11 (StatSoft inc., Tulsa, OK, USA). Data on gonads were first subjected to regression analyses to investigate possible relations between nutrient status and the gonadosomatic index (GSI). Gonads that weighed less than 5\% of body weight (GSI's less than 5) turned out to have a different nutrient status than the larger gonads (GSI at or above 5, Figure 2) and were omitted from the study. The omitted fish all belonged to the farmed group. The data were then analyzed using the student t-test and the Mann-Whitney U test.

Data on nutrient composition of juveniles were analyzed for homogenous variances using Levenes test. Those nutrients where the data had homogenous variances were analyzed by one 
way ANOVA and Tukeys Honest Significant Difference post hoc test for unequal sample sizes. All juvenile nutrient status data were also analyzed using the Kruskal-Wallis test and nonparamtric analyses of differences between groups were performed with the Mann-Whitney U test.

\section{Results}

\section{The macronutrient experiment}

The analyzed levels of macronutrients were different from the formulated levels. Analyzed protein was 3.5\% higher than the formulated level at 77\% supplementation but the difference decreased gradually to approximately $2 \%$ at the lower supplementation levels. Carbohydrate level in the diet was calculated by subtraction and was up to $4 \%$ lower than formulated in the 5\% supplementation, but the difference decreased with increased supplementation and was close to zero at $20-25 \%$ supplementation. Analyzed ash was $0.7 \pm 0.2 \%$ lower than formulated while analyzed and formulated lipid levels were similar. The weight\% of raw materials contributing with dietary carbohydrate was 1.17-1.18 times the formulated carbohydrate levels in all cases. Further results are based on the formulated levels of macronutrients. The variation in final weight of fish fed diets with systematic variation in protein, lipid and carbohydrate (Figure 1a) followed the cubic model given in Table $4\left(\mathrm{R}^{2}=0.96, \mathrm{p}=4 * 10^{-4}\right)$. The composition which gave the maximum final weight was approximately $70 \%$ protein, $10 \%$ lipid and $12.5 \%$ carbohydrate. The maximum and minimum measured final weights were 5.0 g and $3.3 \mathrm{~g}$, respectively. Fish fed the commercial control diet weighed 3.4g. A cubic model also gave the best fit to the data on total length $\left(R^{2}=0.84, p=0.03\right.$; Figure $1 b$; Table 4$)$, the diet for obtaining the maximum length being $65 \%$ protein, $12 \%$ lipid and $16 \%$ carbohydrate. Maximum and minimum measured final lengths were 6.4 and $5.7 \mathrm{~cm}$, respectively, while the fish fed the commercial control diet were $5.9 \mathrm{~cm}$. For condition factor, a quadratic model gave the best fit $\left(\mathrm{R}^{2}=0.86, \mathrm{p}=0.002\right.$; Figure $1 \mathrm{c}$, Table 4$)$, with the highest factor at or above $78 \%$ 
protein, $10 \%$ or less lipid and $5 \%$ or less carbohydrate. The maximum and minimum measured condition factors were 1.85 and 1.52, respectively, while fish fed the control diet had a condition factor of 1.53 . The variation in the other measured responses was not systematic, and could not be described by a significant model. The average values for all experimental groups in survival, hepatosomatic index and biochemical composition of whole body and liver are given in Table 5, together with the values for fish fed the commercial control diet.

\section{Nutrient composition of the diets}

Two diets fed to Ballan wrasse were sampled for analyses of nutrient composition; the Labrus diet and the Vitalis+shrimp diet. The Vitalis+shrimp diet was analysed in 2010 and 2011, to cover the period of feeding that may have affected the gonad composition in the broodstock. The results from analysis of the diets are given in Table 2. The Labrus diet was characterized by a low lipid level of $13 \%$ and a moderate protein level of $54 \%$. The Vitalis diet and the diet blend with Vitalis and shrimp had high protein levels at 58 and 62\% and lipid levels at 18 and $21 \%$, respectively. Protein requirements in fish in general vary from 30 to $60 \%$ of dry matter (NRC 2011). Taurine was only analyzed in the Labrus diet and in the Vitalis+shrimp diet in 2011 with similar results at 3.9 and $3.7 \mathrm{~g} \mathrm{~kg}^{-1} \mathrm{DM}$, respectively.

All the water-soluble vitamins were present above the requirements given by (NRC 2011) in all diets. This was also true for vitamin $\mathrm{A}$ and for vitamin $\mathrm{D}$ in the diets where it was measured. Vitamin E was not analyzed in the Labrus diet, it was 10 fold above the requirement in the Vitalis diet, more than 5 fold above the requirement in the Vitalis + shrimp diet in 2010, but below the requirement in the Vitalis+shrimp diet in 2011. For vitamin K both menadione bisulfit (MSB, the synthetic form used for feed supplementation) and the sum of vitamin K originating from the feed ingredients were analyzed. The latter was slightly above 
$0.1 \mathrm{mg} \mathrm{kg}^{-1}$ in all diets, e.g. up to 10 fold higher than MSB. The requirement for vitamin $\mathrm{K}$ in fish is not known. Astaxanthin was present in all diets at $36-57 \mathrm{mg} \mathrm{kg}^{-1}$, except in the Vitalis+shrimp diet in 2011 where astaxanthin was not detected. Astaxanthin from shrimp is probably largely present as esters, and is not detected by our analytical method. It is not known if Ballan wrasse has a requirement for astaxanthin.

The macrominerals, Fe and I were only analyzed in the Labrus diet and in the Vitalis+ shrimp diet in 2011. Ca, Na and K were all present in the diets. Requirements are not given for these minerals by NRC (2011), which are probably obtained via sea water. The diets were all above requirements in concentrations of $\mathrm{Mg}, \mathrm{P}$ and $\mathrm{I}$, but the concentrations of Fe were below or in the very low range of requirements in fish (NRC 2011). For the rest of the microminerals; Mn, $\mathrm{Cu}, \mathrm{Zn}$, Se, the levels in all diets were several fold higher than requirements.

The fatty acid compositions of the diets were characterized by differences in the essential fatty acids. The Vitalis diet in 2010 had more than 1\% ARA, 13\% EPA and 12\% DHA of total fatty acids (TFA), while the Vitalis diet in 2011 had 0.6\% ARA, 17\% EPA and 9\% DHA. The Labrus diet had 0.6\% ARA, 9\% EPA and 10\% DHA. The differences in essential fatty acids affected the fatty acid ratios. DHA:EPA was approximately 1 in the labrus diet and the Vitalis+shrimp diet in 2011and 0.5 in the Vitalis+shrimp diet from 2010. The ARA:EPA ratio was also lower in the Vitalis+shrimp diet from 2010 (0.04) than in the other diets (0.07-0.09).

\section{Whole body nutrient profile of farmed and wild fish}

Dry matter \% increased with fish size from 19.7 to $25.6 \%$ of wet weigh in fish with an average weight of 3.0 and $12.7 \mathrm{~g}$, respectively $(\mathrm{p}(\mathrm{ANOVA})=0.0009$; $\mathrm{p}$ (Kruskal-Wallis test) $=0.015$ (this sequence of tests is used throughout); Table 6). The dry matter of the largest cultured fish group was not different from the wild fish, which had an average weight of 430 g and a dry matter of $26.3 \%$. Protein and glycogen measured on a dry matter basis did not 
differ between the analyzed groups. Fish fed Vitalis+shrimp had a higher lipid level than fish fed the Labrus diet (p(ANOVA)=0.002, p(Kruskal-Wallis); ns), while the wild fish was intermediate in lipid. Taurine concentration was lower in fish fed the Vitalis+shrimp diet than in the Labrus fed fish and the wild fish.

The concentrations of water-soluble vitamins were similar or higher in cultured than in wild fish ( $\mathrm{p} \leq 10^{-4} ; \mathrm{p} \leq 0.01$; Table 6$)$. The exception was niacin, which was lower in fish fed the Vitalis+shrimp diet than in wild fish (p (MwU test)=0.04). The concentrations of vitamin A and vitamin D were up to 9 fold higher in wild fish than in cultured fish $(p \leq 0.03 ; p=0.003$; Table 6).The concentration of vitamin E was similar or higher in cultured fish than in wild fish. The concentration of vitamin K was lower in the groups G01-2011 (Labrus feed) and G01-G02- 2010 (Vitalis + shrimp) than in wild fish ( $\mathrm{p} \leq 0.04$, MwU-test) and similar to wild fish in group G02-2010 (Labrus feed).

Of the macrominerals (Table 6), there was no difference between wild and cultured fish in Ca and P. However, the standard deviations were large and may have masked a possible difference between the fish fed the Vitalis+shrimp diet and the wild fish which had average Ca concentrations of 30 and $41 \mathrm{~g} \mathrm{~kg}^{-1} \mathrm{DM}$ and $\mathrm{P}$ concentrations of 23 and $29 \mathrm{~g} \mathrm{~kg}^{-1} \mathrm{DM}$, respectively. Furthermore, there was a good correlation between Ca and P concentration in these samples $\left(\mathrm{R}^{2}=0.82\right)$. In the cultured fish, $\mathrm{Mg}$ concentrations appeared to decrease with increased fish weight ( $\mathrm{p}=0.0002 ; \mathrm{p}=0.01)$. Mg concentration in G02-2011 was significantly higher than the concentration in G01-02-2010 and in wild fish ( $\mathrm{p}=0.0005$ and $\mathrm{p}=0.003$, respectively). The other cultured groups had intermediate concentrations. K was higher in G02-2011 than in wild fish ( $\mathrm{p}=0.014)$, but similar to wild fish in the other cultured groups. $\mathrm{Na}$ concentration in the cultured fish decreased with increasing size (p (KW test) $=0.004)$ and was similar to the wild fish in the largest group (G01-02-2010). 
Of the microminerals, iron was lower in cultured than in wild fish ( $\mathrm{p}=0.02 ; \mathrm{p}=0.02$; Table 6 ). Zinc decreased with increasing fish weight $(\mathrm{p}=0.0005 ; \mathrm{p}=0.001)$ and was similar in the largest cultured group and in wild fish. There were no differences between wild and cultured fish in the concentrations of $\mathrm{Cu}, \mathrm{Mn}$ and Se.

There were no differences in the levels of the fatty acids 16:0 and 18:1n-9 between the fish groups (Table 6). The percent 18:2n-6 of total fatty acids (TFA) varied between the groups ( $p=0.01 ; p=0.003$ ). Even though there were small differences in 18:2n-6 between G01 and G02-2011, it was nominally small and the groups can be regarded as biologically similar. The concentration in G01-02-2010 was significantly different from all other groups and intermediate, while the wild fish had the lowest concentration. Arachidonic acid (ARA; 20:4n-6) was similar in the three groups of cultured fish at $0.5-0.7 \%$ of TFA while the average concentration in wild fish was $2.4 \%$ of TFA ( $\mathrm{p}(\mathrm{KW}$ test $)=0.004)$. EPA was higher in the fish fed the Vitalis+shrimp diet than in the other groups $\left(\mathrm{p}=10^{-6} ; 0.02\right)$ which were similar. DHA was lower in fish fed the Vitalis+shrimp diet (p (MwU test)=0.04) than in wild fish, but similar to wild fish in the other cultured groups. The DHA/EPA ratio was the lowest at 0.72 in the fish fed the Vitalis+shrimp diet, and statistically similar at average values of 1.8-2.4 in the other groups ( $\mathrm{p}=0.001 ; \mathrm{p}=0.02$ ). The ARA/EPA ratio was higher in the wild fish (average 0.17) than in the cultured fish (average 0.05-0.07; p (KW test)=0.005).

\section{Nutrient profiles of female gonads from mature wild wrasse and mature wrasse held in captivity for one year}

There were no significant differences in weight or length of the wild and captive fish sampled for analyses (Table 8), however the captive fish had higher mean values, and a large variation may have masked possible differences. The gonadosomatic index (GSI) was significantly lower in captive than in wild fish (p (t-test)=0.01). The concentration of nutrients in the 
gonads changed when GSI dropped below 5, as shown in Figure 2. Therefore, fish with GSI lower than 5 were omitted from the data on nutrient composition of female gonad given in Table 8.

GSI was similar in the two groups after fish with low GSIs had been removed from the group of captive fish (Table 8). Dry matter, protein and total fatty acids were also similar in gonads from wild and captive fish, but taurine was lower in captive than in wild gonad (p $(\mathrm{t}$-test $)=0.002 ; \mathrm{p}(\mathrm{MwU}$ test $)=0.014$ (this sequence of tests is used throughout); Table 8). The water-soluble vitamins and vitamin $E$ were similar or higher ( $\mathrm{p} \leq 0.01 ; \mathrm{p} \leq 0.03)$ in the captive, compared to the wild group while the concentration of vitamin D was approximately half in captive compared to wild fish ( $\mathrm{p}=0.04 ; \mathrm{p}=0.04)$,. Vitamin $\mathrm{K}$ was not analyzed in the captive group due to shortage of sample material. Astaxanthin was not detected in gonad from wild fish, but was present in gonad from captive fish.

Of the minerals, no differences were found between wild and captive fish in $\mathrm{Ca}, \mathrm{Mg}, \mathrm{P}, \mathrm{Cu}$ and Se. $\mathrm{Na}(\mathrm{p}=0.01 ; \mathrm{p}=0.03)$ and $\mathrm{K}(\mathrm{p}=0.025 ; \mathrm{ns})$ were higher in captive than in wild fish. Moreover, a higher concentration of Mn (30\%; ns; p=0.03) and Zn (50\%; p=0.0001; p=0.001) was determined in captive compared to wild fish, while I was present in captive fish at about $1 / 3$ of the concentration in wild fish.

The most important differences in fatty acid composition were those of ARA, EPA and DHA. ARA was lower $(\mathrm{p}=0.0002 ; \mathrm{p}=0.001)$, EPA higher $\left(\mathrm{p}<10^{-7} ; \mathrm{p}=0.01\right)$ and DHA lower $(\mathrm{p}=0.01$; $\mathrm{p}=0.015$ ) in gonad from captive compared to wild fish. This resulted in large differences in essential fatty acid ratios, DHA:EPA being 1.53 and $2.53(\mathrm{P}=0.0004 ; \mathrm{p}=0.0014)$ and ARA:EPA ratios being 0.10 and $0.49\left(\mathrm{p}<10^{-5} ; \mathrm{p}=0.0014\right)$ in gonads from captive and wild fish, respectively. There was also a statistically significant difference in 18:1n-9 which amounted to 7 and $8 \%$ of TFA, respectively ( $p=0.001 ; p=0.003$ ). 


\section{Discussion}

The present study aimed at developing functioning diet formulations for Ballan wrasse within a short time frame. Currently, the industry is establishing wrasse culture for controlling salmon lice, but fulfilling the nutritional requirements of both the on-growing and broodstock fish are bottlenecks in the production line. To determine the optimum macronutrient composition in diets for juveniles we have run a three component mixture design varying protein, lipid and carbohydrate in a systematic manner and recording differences in growth, survival and body composition. One can assume that broodstock have similar macronutrient requirements as juveniles, however this should be validated in future studies. To investigate whether fish in culture obtain a sufficient supply of taurine, fatty acids, and micronutrients, we analyzed the status of these nutrients in cultured and wild fish. Wild fish were used as a reference, on the assumption their nutrient requirements are covered by their natural diet. Whole body analyses were used to assess the nutrient status of juveniles and analyses of female gonad to investigate broodstock nutritional status.

In the experiment on dietary macronutrient composition, the best growth (length and weight based) was obtained with diets containing $65-70 \%$ protein, $10-12 \%$ lipid and $12.5-16 \%$ carbohydrate. There was a slight difference in maximum between the weight and length data; the highest final weight was obtained at slightly higher protein and lipid levels and a lower carbohydrate level than the highest final length. This may have been caused by overfeeding in fish fed the diets with high protein contents. Until now, Ballan wrasse has had a satisfactory feed intake only when the feed is supplemented with shrimp or shrimp meal (Nordgreen et al., unpublished; Opstad et al., unpublished). In the present study, the protein source was a blend of cod fillet and shrimp at a fixed ratio, which may have led to higher feed intake in fish fed the diets high in protein, and therefore high in shrimp. Due to the small size of the feed particles, feed intakes were not measured. However, the increased condition factors in fish fed high protein diets, indicates that feed intake was probably high in these fish groups. Based on PeerJ reviewing PDF | (v2013:05:466:2:0:NEW 17 Jun 2013) 
these considerations, lengthwise growth may be a better indicator of optimum macronutrient composition than growth in weight and the optimum diet composition would then be $65 \%$ protein, 12\% lipid and 16\% carbohydrate. Fish fed such a diet would have a condition factor at approximately 1.7, which is similar to the average condition factor of the wild mature fish sampled for analyses of female gonad. The optimum diet for wrasse juveniles therefore contains relatively high levels of protein and carbohydrate and a low lipid level.

The lipid level in the diet was increased with the addition of pure oil in the form of triglycerides. Although all diets contained relatively high concentrations of phospholipids from both the marine feed ingredients and the addition of soy lecithin, there was still a large reduction in the relative phospholipid concentrations with increase in total lipid level. In a later experiment, we have shown that wrasse have higher growth rates when the added dietary lipid is in the form of phospholipids as compared to neutral lipids (Sæle et al., unpublished). Thus the optimum dietary macronutrient composition may be dependent on lipid quality. The commercial control feed was included to normalize between experiments. It had been previously tested against other commercial feeds and proven to give better results (Grøtan, unpublished). It differed from the experimental diets in several aspects, but most important, it did not contain shrimp. This alone may explain the low growth and condition factor in fish fed the commercial control diet, compared to those fed the best experimental diets. In the experiments where the nutrient profiles in wild and cultured fish were analyzed, the cultured broodstock were fed on a diet blend with 75\% Vitalis and 25\% minced shrimp. It was a moist diet, blended and pelleted on site. The protein content was similar, at $65 \%$, and the lipid level slightly higher, at 18\%, than the optima found in the macronutrient experiment. The juveniles were fed either with the Vitalis+shrimp diet or with a diet developed for Ballan wrasse (Labrus, Skretting AS) which contained 54\% protein and 13\% lipid. 
Fish whole body dry matter increased with fish size up to 12.5g. Such a weight/dry matter relationship is a common trait for several fish species (Hamre et al., 2002). Dry matter did not differ in gonad from wild and captive fish. Lipid was higher in whole body of juveniles that had been fed the Vitalis+shrimp diet than in those fed the Labrus diet. This may have been caused by a higher dietary lipid level, which often increased body lipid content in fish (Aksnes et al., 1996; Hamre et al. 2003; Karlsen et al. 2006). However, the Vitalis+shrimp diet was moist and included fresh shrimps, which may have stimulated increased feed- and hence energy intake, contributing to increased body lipid levels. There were no differences in lipid levels between fish fed the Vitalis+shrimp diet and the wild fish, either for juveniles or for broodstock. Protein in whole body given on a dry weight basis was similar among all groups of juveniles and did not differ in wild and captive fish female gonads. Protein levels are largely determined by the genetic code of healthy and feeding animals, however, when measured on a dry weight basis it may be lowered at high levels of body lipid, since lipid replaces water in the body. There was a tendency to lower protein level in the Vitalis+shrimp group, but no significant difference. Taurine is a non protein amino acid, which among others, is involved in osmoregulation and bile salt production. It is essential for cats and has been shown to be essential in the early stages of some marine fish species (Sturman 1993; Chen et al. 2005; Chen et al. 2004; Pinto et al. 2010). The level of taurine was lower both in juveniles and in broodstock fish fed the Vitalis+shrimp diet compared to wild fish and fish fed the Labrus diet. The taurine levels in the two diets were similar, so the difference was probably due to differences in absorption, utilization and/or excretion of taurine, which again may be coupled to differences in dietary lipid levels. The requirement for taurine needs further investigation.

The water-soluble vitamins consist of vitamin C and the B-vitamins. Vitamin C functions as a water-soluble antioxidant and is also involved in numerous biochemical reactions, e.g. 
hydroxylation of proline to hydroxyproline during synthesis of connective tissue (Sandnes et al. 1992; Meister 1994). The B-vitamins are cofactors in intermediary metabolism. The dietary concentrations of water-soluble vitamins were mainly at or above the requirements in fish given by NRC (2011) and similar or higher in cultured fish compared to wild fish, both for juveniles and broodstock. The one exception was the level of niacin in whole body of juveniles fed the Vitalis+shrimp diet, which was lower than in wild fish. The very high levels of some of the water-soluble vitamins in the diets were not reflected in the fish, possibly because excess of water-soluble vitamins are easily excreted from the body. The lipid soluble vitamins consist of vitamin A, D, E and K. Vitamin E is a lipid soluble antioxidant protecting the fish against in vivo lipid oxidation (Hamre 2011). Vitamin E was present in cultured fish at or above the levels found in wild fish. Vitamin A is involved in regulation of cell proliferation and differentiation, and among others, is important for the integrity of the skin and development of body and organ axes in embryogenesis (Maden 1994). Astaxanthin is converted to vitamin A in Atlantic halibut (Moren et al. 2002), possibly also in other fish, and can be considered a pro-vitamin A form. Vitamin A levels in the diets were slightly above the optimum level of $2.4 \mathrm{mg} \mathrm{kg}^{-1}$ dry diet found for Atlantic halibut by Moren et al. (2004), while the minimum fish requirement given by NRC (2011) is $0.8 \mathrm{mg} \mathrm{kg}^{-1}$ dry diet. However, vitamin A was on average 10 fold higher in wild fish than cultured fish, but the individual variation in the wild fish was high. Analysis of vitamin A in female gonads requires a specialized method and was not performed in this study. The body level of lipid soluble vitamins often increases linearly with increasing supplementation to far above the requirement (Hamre et al. 1997; Moren et al. 2004) and lower concentrations of these vitamins in cultured than in wild fish does not necessarily indicate deficiency. The required vitamin A status in Ballan wrasse is therefore not known and needs further study. Vitamin D is involved in regulation of calcium and phosphorus homeostasis, important, among other 
things, for bone health (Lock et al. 2010). Vitamin D was also higher in wild fish than in cultured fish, 4-9 fold in the juveniles and 2 fold in the broodstock. The vitamin D status in the different cultured juvenile groups was similar and vitamin D levels were similar in the two analyzed diets, 2-10 fold higher than the requirement given by NRC (2011). As for vitamin A, the required vitamin D status in Ballan wrasse is not known and should be investigated further. Vitamin K is involved in carboxylation reactions, such as blood clotting and bone formation (Krossøy et al. 2011). The dietary concentration of vitamin K originating from the feed ingredients was several fold higher than the added menadione bisulfitt (MSB) and similar in the different diets. The concentration of vitamin $\mathrm{K}$ in whole body of cultured juveniles seemed to decrease with increasing fish size. The two largest cultured juvenile groups had a vitamin K status that was $<25 \%$ of the average wild fish status. Again, the wild fish data showed large variation. As for vitamin $\mathrm{A}$ and $\mathrm{D}$, the requirement of vitamin $\mathrm{K}$ in Ballan wrasse needs further investigation.

Calcium, magnesium and phosphorus can be classified as bone minerals. In broodstock, there were no differences in the concentration of these minerals between wild and cultured fish. No significant difference was found in calcium and phosphorus between wild and cultured juveniles. Fish fed the Labrus diet had similar means as the wild fish, but in fish fed the Vitalis+shrimp diet, the mean values of calcium and phosphorus levels were about $75 \%$ of the levels found in wild fish. For phosphorus, this corresponded to a difference in dietary levels. Magnesium was significantly lower in fish fed the Vitalis+shrimp diet than in fish fed the Labrus diet. This corresponded to a difference in the dietary magnesium concentration, which was, however, 4-6 fold higher than the requirement given by NRC (2011). None of the cultured fish groups had significant lower magnesium status than the wild fish, but the mean level in fish fed the Vitalis+shrimp diet was again $75 \%$ of the average in wild fish, while Labrus feed gave similar or higher means than in wild fish. Therefore, even though the 
differences were not significant, the requirements for bone minerals should be further investigated.

Sodium and potassium are classified as electrolytes, involved in osmoregulation in extra and intracellular spaces, respectively. Both minerals decreased in concentration with increasing fish weight. Potassium was 50\% and sodium 100\% higher in the smallest cultured group of juveniles versus the wild fish, but no other differences in whole fish were observed. Both sodium and potassium were higher in gonads from captive compared to wild fish. The captive and cultured fish had a high frequency of wounds and fin erosion, which may have led to an influx of sodium from the sea water. Increased intracellular potassium may then have been required to osmoregulate against the high extracellular sodium. The problem with excess electrolytes can probably be solved only by identifying the causes for the wounds and implementing the necessary rearing adjustments. An extensive amount of work is currently invested in this issue.

In the present study, diet levels of iron were at or below the minimum requirement given by NRC (2011). Still, iron was higher in gonad from cultured fish than in wild fish. In juveniles, the iron status in the cultured fish groups was similar to each other, but lower than in wild fish. One could try to assess iron status in fish fed a diet supplemented with iron in the upper range of requirement and see if it becomes more similar to that in wild fish. Iodine was lower in gonad from cultured compared to wild fish, although dietary iodine concentration was well above the requirement given by NRC (2011). Zinc levels were higher in gonads from cultured compared to wild fish. The dietary levels of zinc were similar, while zinc in juveniles appeared to decrease with increasing fish size, the largest cultured group being similar to wild fish. It is not known if the ranges of zinc found in the present study are within the safe range for Ballan wrasse. There were no differences in selenium and copper between wild and 
cultured fish. Overall, the iron, zinc and iodine requirements in Ballan wrasse require further investigation.

The fatty acid composition was quite different between wild and cultured fish, and between fish fed the Vitalis+shrimp diet compared to fish fed the Labrus diet. ARA was 3-5 fold higher in wild compared to cultured fish, both in broodstock and juveniles. EPA was higher in fish fed the Vitalis+shrimp diet, but similar in juveniles fed the Labrus diet and wild fish. DHA was slightly lower in juveniles fed the Vitalis+shrimp diets and in broodstock, than in wild fish. Consequently, the DHA:EPA ratio was approximately 2 in fish fed the Labrus diet, which is the recommended level in eggs (Sargent 1995). Broodstock and juveniles fed the Vitalis+shrimp diet had DHA:EPA ratios of 1.5 and 0.72, respectively. The ARA:EPA ratio was $<0.1$ in the cultured fish and 0.3-0.5 in wild fish. This ratio is hypothesized to be important for spawning performance in marine fish (Furuita et al. 2003; Mazorra et al. 2003). In the present study, the broodstock diets contained $0.6 \%$ ARA, whereas in cod a dietary level of ARA of 1-2\% of fatty acids gave the best spawning performance (Norberg et al. 2009). Broodstock diets for Ballan wrasse should probably be supplemented with more ARA, while the ARA level in feed for on-growing may be less critical. It is not known if the differences in EPA, DHA and their ratios are critical for Ballan wrasse. A number of marine fish species are fed on diets high in plant ingredients, without major negative effects. The safe ranges of diet fatty acid composition for Ballan wrasse should be investigated further.

\section{Conclusion}

The optimum dietary macronutrient composition for juvenile Ballan wrasse according to the present study is $65 \%$ protein, $12 \%$ lipid and $16 \%$ carbohydrate, based on maximum lengthwise growth. The high optimum protein content may have been affected by the quality 
of the dietary ingredients, since shrimp was used as a fixed part of the protein source and may have functioned as an attractant. Furthermore, later studies have shown that the lipid class composition of added lipid has a large effect on growth, and lipid quality will probably affect the optimum macronutrient composition.

Based on chemical analysis, the diets used for culture of Ballan wrasse contained sufficient amounts of the micronutrients, except iron, according to NRC (2011). The macronutrient and the fatty acid compositions were slightly different from assumed optima.

Of the nutrients analyzed in juveniles and broodstock, the least need for further investigation is in water-soluble vitamins, vitamin E, selenium and copper. The high levels of electrolytes in cultured fish were probably due to wounds and fin erosion and are of minor interest when it comes to nutrition. The levels of bone minerals in wild and cultured fish were not significantly different, but should be investigated further as large differences were observed in mean values. Adjustments should be done in ARA and iodine for broodstock, and in iron both for broodstock and juveniles.

Vitamin A, D and K were all higher in wild fish than in cultured fish. These vitamins do not usually show a clear relationship between body level and requirement, so it is unknown if the requirements were covered in the cultured fish. Moreover, there are several different forms of each of these vitamins, and there are relatively few studies on the requirements in fish, at least for vitamin D and $\mathrm{K}$. These are all reasons that the requirements for these vitamins in Ballan wrasse deserve further studies. Taurine and zinc are other possible candidates for more in-depth investigations.

\section{Acknowledgements}

Many thanks to Kjersti Ask, NIFES, who organized the analyses of the samples, to the technical staff at NIFES who performed the analyses and to Karen Kvalheim and Henning 
Sandøy at Marine Harvest Labrus, Reidun Bjelland and Anne Berit Skiftesvik at the Institute of Marine Research for help with sampling of fish. We also thank Samuel J. Penglase for improving the language of the manuscript.

\section{References}

Aksnes A, Hjertnes, T, Opstvedt, J. 1996. Effect of dietary protein level on growth and carcass composition in Atlantic halibut (Hippoglossus hippoglossus L). Aquaculture 145:225-233.

Bjørn PA, Karlsen Ø, Jansen PA, Johnsen IA, Nilsen P, Llinnares RMS, Asplin L, Skilbrei O, Finstad B, and Taranger GL. 2012. Risikovurdering lakselus. In: Taranger GL, Svåsand T, Kvamme BO, Kristiansen TS, and Boxaspen KK, eds. Risikovurdering av norsk fiskeoppdrett. Bergen, Norway: Institute of Marine Research, 14-40.

CEN ( Comitè Europèen de Normalisation ), prEN 12821 (1999), Foodstuffs - Determination of vitamin D by high performance liquid chromatography - Measurement of cholecalciferol (D3) and ergocalciferol (D2).

CEN (Comitè Europèen de Normalisation), (2003), EN 14122, Foodstuffs -Determination of Vitamin B1 by HPLC; 17pp.

CEN (Comitè Europèen de Normalisation) 2003 EN 14152 Foodstuffs -Determination of Vitamin B2 by HPLC; 14pp.

CEN ( Comitè Europèen de Normalisation ), EN 14148 (2003), Foodstuffs - Determination of vitamin K1 by HPLC.

CEN (Comitè Europèen de Normalisation) (2005) EN 14663, Foodstuffs - Determination of vitamin B6 (including its glycosylated forms) by HPLC 
Chen JN, Takeuchi T, Takahashi T, Tomoda T, Koisi M, and Kuwada H. 2005. Effect of rotifers enriched with taurine on growth in larvae of Japanese flounder Paralichthys olivaceus. Nippon Suisan Gakkaishi 71:342-347.

Chen JN, Takeuchi T, Takahashi T, Tomoda T, Koiso M, and Kuwada H. 2004. Effect of rotifers enriched with taurine on growth and survival activity of red sea bream Pagrus major larvae. Nippon Suisan Gakkaishi 70:542-547.

Cornell JA. 1990. Experiments with mixtures: John Wiley \& Sons, Inc.

Espe M, Lemme A, Petri A, and El-Mowafi A. 2006. Can Atlantic salmon (Salmo salar) grow on diets devoid of fish meal? Aquaculture 255:255-262.

European Commission (1983) Determination of crude oils and fats. Commission directive 84/4, Annex 1. Official Journal Of the European Communities, No L 15/29.

Figueiredo M, Morato T, Barreiros JP, Afonso P, and Santos RS. 2005. Feeding ecology of the white seabream, Diplodus sargus, and the Ballan wrasse, Labrus bergylta, in the Azores. Fisheries Research 75:107-119.

Furuita H, Yamamoto T, Shima T, Suzuki N, and Takeuchi T. 2003. Effect of arachidonic acid levels in broodstock diet on larval and egg quality of Japanese flounder Paralichthys olivaceus. Aquaculture 220:725-735.

Hamre K. 2011. Metabolism, interactions, requirements and functions of vitamin E in fish. Aquaculture Nutrition 17:98-115.

Hamre K, Berge RK, Waagbø R, and Lie, Ø. 1997. Vitamins C and E interact in juvenile Atlantic salmon (Salmo salar, L.). Free Radical Biology Medicine 22:137-149.

Hamre K, Kolas K, and Sandnes K. 2010. Protection of fish feed, made directly from marine raw materials, with natural antioxidants. Food Chemistry 119:270-278. 
Hamre K and Mangor-Jensen A. 2006. A multivariate approach to optimization of macronutrient composition in weaning diets for cod (Gadus morhua). Aquaculture Nutrition 12:15-24.

Hamre K, Øfsti A, Næss T, Nortvedt R, and Holm JC. 2003. Macronutrient composition of formulated diets for Atlantic halibut (Hippoglossus hippoglossus, L.) juveniles. Aquaculture 227:233-244.

Hamre K, Opstad, I, Espe, M, Solbakken, J, Hemre, G-I, Pittman, K. 2002. Nutrient composition and metamorphosis success of Atlantic halibut (Hippoglossus hippoglossus, L.) larvae fed natural zooplankton or Artemia. Aquaculture Nutrition 8:139-148.

Hamre K and Sæle Ø. 2011. Oppdrett av leppefisk til lakselusbekjempelse: Hva står på menyen. Norsk Fiskeoppdrett 9/2011:70-72.

Horsberg TE. 2000. Farmakologi av antiparasitt midler brukt mot lakselus. In: Wesenberg GR, and Bredal W, eds. Behandling mot lakselus i oppdrettsanlegg: The Norwegian Medicines Control Authority Publications 2000:02, 47pp, 47pp.

Julshamn K, Dahl L, and Eckhoff K. 2001. Determination of iodine in seafood by inductively coupled plasma/mass spectrometry. Journal of AOAC International 84:1976-1983.

Julshamn K, Lundebye AK, Heggstad K, Berntssen MHG, and Bøe B. 2004. Norwegian monitoring programme on the inorganic and organic contaminants in fish caught in the Barents Sea, Norwegian Sea and North Sea, 1994-2001. Food Additives and Contaminants 21:365-376.

Julshamn K, Maage A, Norli HS, Grobecker KH, Jorhem L, and Fecher P. 2007. Determination of arsenic, cadmium, mercury, and lead by inductively coupled plasma/mass spectrometry in foods after pressure digestion: NMKL1 interlaboratory study. Journal of AOAC International 90:844-856. 
Karlsen O, Hemre GI, Tveit K, and Rosenlund G. 2006. Effect of varying levels of macro-nutrients and continuous light on growth, energy deposits and maturation in farmed Atlantic cod (Gadus morhua L.). Aquaculture 255:242-254.

Krossøy C, Waagbø R, and Ørnsrud R. 2011. Vitamin K in fish nutrition. Aquaculture Nutrition 17:585-594.

Kvenseth PG. 2011. Leppefiskhistorie fra 1967 til 2010 - og ti år frem i tid. Norsk Fiskeoppdrett 6a; Rensefisk. Bergen, Norway. p 12-13.

Lek E, Fairclough DV, Platell ME, Clarke KR, Tweedley JR, and Potter IC. 2011. To what extent are the dietary compositions of three abundant, co-occurring labrid species different and related to latitude, habitat, body size and season? Journal of Fish Biology 78:1913-1943.

Lie, $\varnothing$ and Lambertsen, G. 1991. Fatty acid composition of glycerophospholipids in seven tissues of cod (Gadus morhua), determined by a combined HPLC/GC method. Journal of Chromatography 565.

Lie, Ø, Waagbø R, and Sandnes, K. 1988. Growth and chemical composition of adult Atlantic salmon (Salmo salar) fed dry and silas based diets. Aquaculture 69.

Lock EJ, Waagbø R, Bonga SW, and Flik G. 2010. The significance of vitamin D for fish: a review. Aquaculture Nutrition 16:100-116.

Maden M. 1994. Role of retinoids in embryonic development. In: Blomhoff R, ed. Vitamin A in health and disease. New York, Basel, Hong Kong: Marcel Dekker, Inc., 289-322.

Mazorra C, Bruce M, Bell JG, Davie A, Alorend E, Jordan N, Rees J, Papanikos N, Porter M, and Bromage N. 2003. Dietary lipid enhancement of broodstock reproductive performance and egg and larval quality in Atlantic halibut (Hippoglossus hippoglossus). Aquaculture 227:21-33. 
Meister A. 1994. Glutathione Ascorbic Acid Antioxidant System in Animals. Journal of Biological Chemistry 269:9397-9400.

Moren M, Næss T, and Hamre K. 2002. Conversion of beta-carotene, canthaxanthin and astaxanthin to vitamin A in Atlantic halibut (Hippoglossus hippoglossus L.) juveniles. Fish Physiology and Biochemistry 27:71-80.

Moren M, Opstad I, Berntssen MHG, Infante JLZ, and Hamre K. 2004. An optimum level of vitamin A supplements for Atlantic halibut (Hippoglossus hippoglossus L.) juveniles. Aquaculture 235:587-599.

Mortensen S, and Karlsbakk E. 2012. Risiko ved bruk av leppefisk i norsk akvakultur. In: Taranger GL, Svåsand T, Kvamme BO, Kristiansen TS, and Boxaspen KK, eds. Risikovurdering av norsk fiskeoppdrett. Bergen, Norway: Institute of Marine Research, 111-120.

Mæland A, Rønnestad I, Fyhn HJ, Berg L, and Waagbø R. 2000. Water-soluble vitamins in natural plankton (copepods) during two consecutive spring blooms compared to vitamins in Artemia franciscana nauplii and metanauplii. Marine Biology 136:765-772.

Mæland A, and Waagbø R. 1998. Examination of the qualitative ability of some cold water marine teleosts to synthesise ascorbic acid. Comparative Biochemistry and Physiology Part A 121:249-255.

Norberg B, Hamre K, Araujo P, Meeren Tv, and Rosenlund G. 2009. Effect of graded levels of arachidonic acid on reproductive physiology, spawning performance and egg quality of Atlantic cod. Larvi 2009. Ghent, Belgium.

NRC. 2011. Nutrient requirements of fish and shrimp: The Natioanal Academic Press, Washington D.C. 
Pinto W, Figueira L, Ribeiro L, Yufera M, Dinis MT, and Aragao C. 2010. Dietary taurine supplementation enhances metamorphosis and growth potential of Solea senegalensis larvae. Aquaculture 309:159-164.

Sandnes K, Torrissen O, and Waagbø R. 1992. The minimum dietary requirement of vitamin $\mathrm{C}$ in Atlantic salmon (Salmo salar) fry using Ca-ascorbate-2-monophosphate as dietary source. Fish Physiology and Biochemistry 10:315-319.

Sargent JR. 1995. Origin and functions of egg lipids. In: Bromage NR, and Roberts RJ, eds. Broodstock management and egg and larval quality. London: Blackwell Science, 353-372.

Sturman JA. 1993. Taurine in development. Physiological Reviews 73:119-147.

Ørnsrud R, Wargelius A, Sæle Ø, Pittman K, and Waagbø R. 2004. Influence of egg vitamin A status and egg incubation temperature on subsequent development of the early vertebral column in Atlantic salmon fry. Journal of Fish Biology 64:399-417. 


\section{Table $\mathbf{1}_{\text {(on next page) }}$}

Diets for the macronutrient experiment. A. Basic formulation. B. Nutrient composition, formulated. C. Nutrient composition, analyzed.

${ }^{a}$ Fresh fillet from wild caught Atlantic cod. ${ }^{b}$ Shrimp powder (7411), Seagarden AS, Avaldsnes Norway ${ }^{\mathrm{c}}$ Norsalmoil ${ }^{\circledR}$, produced from Capeline. Egersund Sildeoljefabrikk AS, Egersund Norway. ${ }^{\mathrm{d}}$ Suprex Corn fine, Codrico, Rotterdam Netherlands. ${ }^{\mathrm{e}}$ Wheat grain (510130), Norgesmøllene AS, Nesttun Norway. ${ }^{\text {f }}$ Soylecithin GMO powder (20022), Agrosom, Mölln Germany ${ }^{g}$ D3 3000 IE kg ${ }^{-1}$, E $160 \mathrm{mg} \mathrm{kg}^{-1}$, K3 $20 \mathrm{mg} \mathrm{kg}^{-1}$, C $500 \mathrm{mg} \mathrm{kg}^{-1}$, B1 $20 \mathrm{mg} \mathrm{kg}^{-1}$, B2 $30 \mathrm{mg} \mathrm{kg}^{-1}$, B6 $25 \mathrm{mg} \mathrm{kg}^{-1}$, B12 5 нg $\mathrm{kg}^{-1}$, B5 $60 \mathrm{mg} \mathrm{kg}^{-1}$, Folic acid $10 \mathrm{mg} \mathrm{kg}^{-1}$, Niacin $200 \mathrm{mg} \mathrm{kg}^{-1}$, Biotin $1 \mathrm{mg} \mathrm{kg}^{-1}$, h BOLIFOR ${ }^{\circledR}$ MSP, Yara AS, Norway. ${ }^{\mathrm{i}} \mathrm{Mn} 30 \mathrm{mg} \mathrm{kg}^{-1}$, Mg $750 \mathrm{mg} \mathrm{kg}^{-1}$, Fe $60 \mathrm{mg} \mathrm{kg}^{-1}$, Zn mg kg${ }^{-1}, 120 \mathrm{mg} \mathrm{kg}^{-1}$,

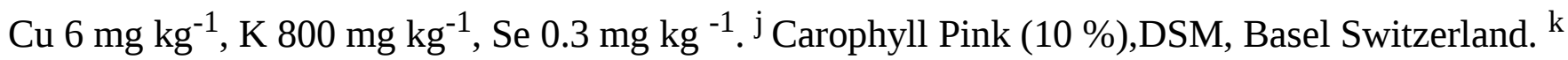
Yttrium(III) oxide, Reacton 99.99 \%, Alfa Aesar, Ward Hill USA. ${ }^{\text {l}}$ EthoxyquinFEQ500, Facet Pharma APS, Valby, Denmark. 


\begin{tabular}{|c|c|c|c|c|c|c|c|c|c|c|c|c|c|}
\hline Diet no & $\begin{array}{c}1 \\
\%(\mathrm{dw})\end{array}$ & $\begin{array}{c}2 \\
\%(\mathrm{dw})\end{array}$ & $\begin{array}{c}3 \\
\%(\mathrm{dw})\end{array}$ & $\begin{array}{c}\mathbf{4} \\
\%(\mathrm{dw})\end{array}$ & $\begin{array}{c}\mathbf{5} \\
\%(\mathrm{dw})\end{array}$ & $\begin{array}{c}\mathbf{6} \\
\%(\mathrm{dw})\end{array}$ & $\begin{array}{c}7 \\
\%(d w)\end{array}$ & $\begin{array}{c}\mathbf{8} \\
\%(\mathrm{dw})\end{array}$ & $\begin{array}{c}9 \\
\%(\mathrm{dw})\end{array}$ & $\begin{array}{c}10 \\
\%(d w)\end{array}$ & $\begin{array}{c}11 \\
\%(\mathrm{dw})\end{array}$ & $\begin{array}{c}12 \\
\%(\mathrm{dw})\end{array}$ & $\begin{array}{c}13 \\
\%(d w)\end{array}$ \\
\hline Cod fillet $^{\mathrm{a}}$ & 71.3 & 63.1 & 54.9 & 46.6 & 62.4 & 54.3 & 46.3 & 37.7 & 53.7 & 45.6 & 37.6 & 28.9 & 23.3 \\
\hline Shrimp meal ${ }^{\mathrm{b}}$ & 15 & 15 & 15 & 15 & 15 & 15 & 15 & 15 & 15 & 15 & 15 & 15 & 15 \\
\hline Fish oill $^{\mathrm{C}}$ & 2.9 & 11.1 & 19.3 & 27.6 & 3.0 & 11.1 & 19 & 27.5 & 3 & 11.1 & 19.3 & 27.5 & 27.4 \\
\hline Corn Suprex ${ }^{\mathrm{d}}$ & $4 . \overline{1}$ & 4.1 & 4.1 & 4.1 & 12.9 & 12.9 & 12.95 & 12.96 & 21.54 & 21.59 & 21.7 & 21.8 & 27.4 \\
\hline Wheat ${ }^{\mathrm{e}}$ & 1.8 & 1.8 & 1.8 & 1.8 & 1.8 & 1.8 & 1.8 & 1.8 & 1.8 & 1.8 & 1.8 & 1.8 & 1.8 \\
\hline Soy lecithine ${ }^{\mathrm{f}}$ & 30 & 3 & 3 & 3 & 3 & 3 & 3 & 3 & 3 & 3 & 3 & 3 & 3 \\
\hline Vitamin $\operatorname{mix}^{\mathrm{g}}$ & $0 \longdiv { 3 }$ & 0.3 & 0.3 & 0.3 & 0.3 & 0.3 & 0.3 & 0.3 & 0.3 & 0.3 & 0.3 & 0.3 & 0.3 \\
\hline Mineral mix ${ }^{\mathrm{h}}$ & 0.55 & 0.55 & 0.55 & 0.55 & 0.55 & 0.55 & 0.55 & 0.55 & 0.55 & 0.55 & 0.55 & 0.55 & 0.55 \\
\hline Mono sodiumphosphate ${ }^{\mathrm{i}}$ & $1 \overline{3}$ & 1 & 1 & 1 & 1 & 1 & 1 & 1 & 1 & 1 & 1 & 1 & 1 \\
\hline Carophyll pink ${ }^{\mathrm{j}}$ & 0.08 & 0.03 & 0.03 & 0.03 & 0.03 & 0.03 & 0.03 & 0.03 & 0.03 & 0.03 & 0.03 & 0.03 & 0.03 \\
\hline Yttrium oxide ${ }^{\mathrm{k}}$ & 0.02 .5 & 0.025 & 0.025 & 0.025 & 0.025 & 0.025 & 0.025 & 0.025 & 0.025 & 0.025 & 0.025 & 0.025 & 0.025 \\
\hline Ethoxiquin $^{1}$ & $0,00 \frac{2}{2} 5$ & 0,0025 & 0,0025 & 0,0025 & 0,0025 & 0,0025 & 0,0025 & 0,0025 & 0,0025 & 0,0025 & 0,0025 & 0,0025 & 0,0025 \\
\hline
\end{tabular}




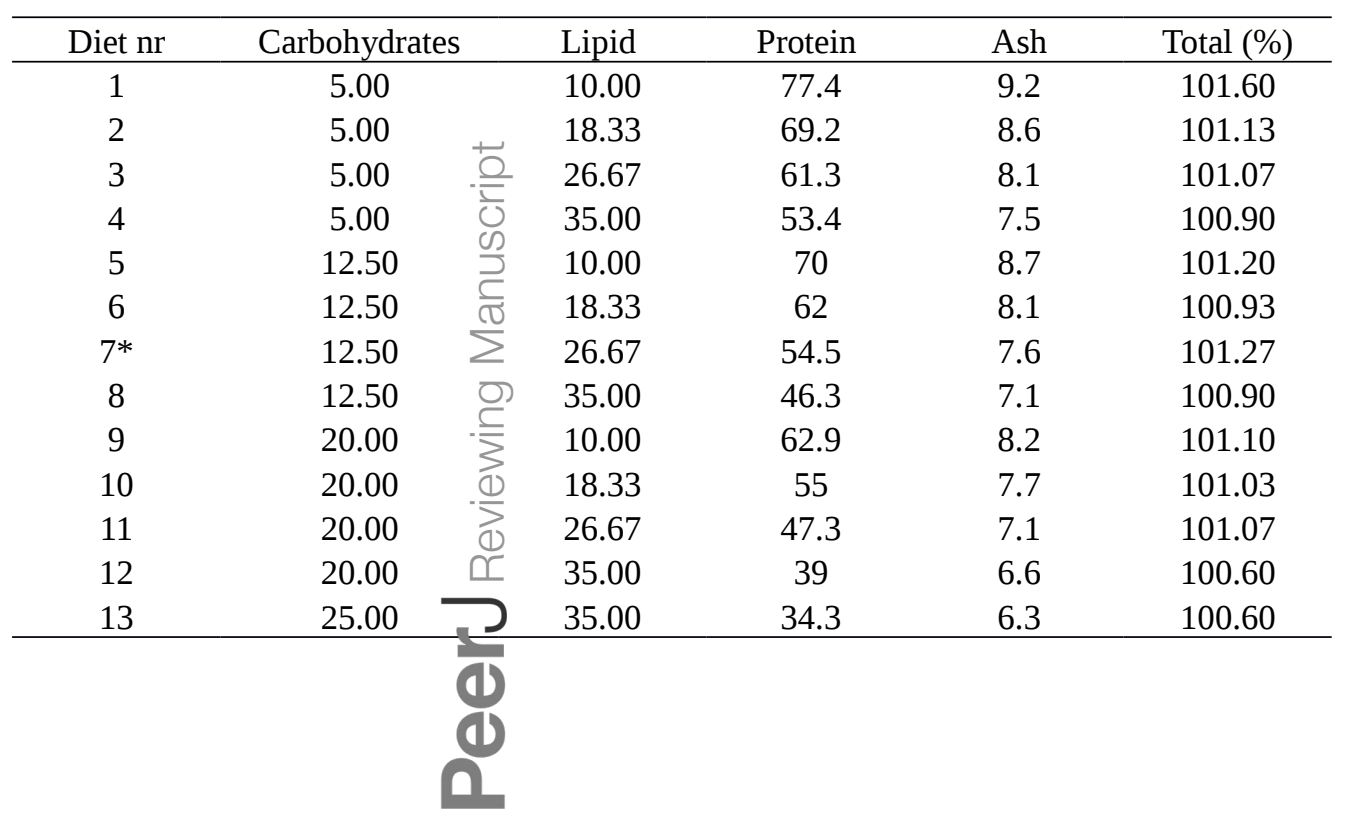




\begin{tabular}{|c|c|c|c|c|}
\hline Diet nr & $\begin{array}{l}\text { Lipid } \\
\text { g/100 g (dw) }\end{array}$ & $\begin{array}{c}\text { Crude protein ( } \mathrm{N} x \text { 6.25) } \\
\mathrm{g} / 100 \mathrm{~g}(\mathrm{dw})\end{array}$ & $\begin{array}{c}\text { Ash } \\
\mathrm{g} / 100 \mathrm{~g}(\mathrm{dw})\end{array}$ & $\begin{array}{c}\text { Carbohydrates (subtraction) } \\
\mathrm{g} / 100 \mathrm{~g}(\mathrm{dw})\end{array}$ \\
\hline 1 & 10.5 & 80.9 & 8.0 & 0.6 \\
\hline 2 & 19.0 & 72.1 & 7.9 & 1.0 \\
\hline 3 & 27.0 & 63.7 & 7.3 & 2.0 \\
\hline 4 & 35.4 & 55.4 & 6.9 & 2.3 \\
\hline 5 & 10.9 & 72.1 & 7.9 & 9.2 \\
\hline 6 & 18.8 & 64.6 & 7.4 & 9.2 \\
\hline 7 & 26.2 & 57.2 & 7.0 & 9.6 \\
\hline 8 & 34.4 & 48.5 & 6.4 & 10.7 \\
\hline 9 & 10.1 & 64.6 & 7.6 & 17.7 \\
\hline 10 & 16.6 & 59.0 & 6.6 & 17.8 \\
\hline 11 & 26.3 & 48.7 & 6.5 & 18.4 \\
\hline 12 & 33.2 & 41.4 & 6.1 & 19.4 \\
\hline 13 & 32.5 & 36.2 & 5.8 & 25.6 \\
\hline
\end{tabular}




\section{Table $2_{\text {(on next page) }}$}

Nutrient composition (in dry matter) of the diets fed to Ballan wrasse juveniles and captive broodstock. A. Macronutrients and taurine. B. Vitamins. C. Minerals. D. Fatty acids.

The juveniles were fed for at least three months and the broodstock for more than one year with the respective diets before sampling. The general requirements for fish according to NRC (2011) are given for comparison. ${ }^{1}$ Labrus feed is an ongrowing diet produced for Ballan wrasse by Skretting AS, Stavanger, Norway. ${ }^{2}$ Vitalis is a broodstock diet produced for marine fish by Skretting AS, Stavanger, Norway. It was blended with shrimp (Vitalis 75\%, Shrimp 25\%) to produce a moist diet at the rearing facility. ${ }^{3}$ Menadione bisulfite is a synthetic form of vitamin K that is usually added to fish feed. Vitamin K is the sum of Phylloquinione and Menakinones 4-11. NR, not required; NT, not tested; -, not given by NRC (2011). 
A

\begin{tabular}{|c|c|c|c|c|c|}
\hline & $\begin{array}{l}\text { Labrus }^{1} \\
+\underline{\underline{\theta}}\end{array}$ & $\begin{array}{c}\overline{\text { Vitalis }^{2}} \\
2010\end{array}$ & $\begin{array}{c}\text { Vitalis+shrimp } \\
2010\end{array}$ & $\begin{array}{c}\text { Vitalis+shrimp } \\
2011\end{array}$ & NRC (2011) \\
\hline Dry matter (\%) &  & 91 & 52 & 60 & - \\
\hline Protein & $\risingdotseq 54$ & 58 & 62 & 60 & $30-60$ \\
\hline Taurine & \. & na & na & 0.37 & NR \\
\hline Lipid & $\underset{d}{d} 13$ & 21 & 18 & 18 & - \\
\hline
\end{tabular}




\begin{tabular}{|c|c|c|c|c|c|}
\hline & $\begin{array}{c}\text { Labrus }^{1} \\
+\frac{0}{=}\end{array}$ & $\begin{array}{c}\text { Vitalis }^{2} \\
2010\end{array}$ & $\begin{array}{c}\text { Vitalis+shrimp } \\
2010\end{array}$ & $\begin{array}{c}\text { Vitalis+shrimp } \\
2011\end{array}$ & NRC (2011) \\
\hline Vitamin C & 455 & 736 & 290 & 768 & 50 \\
\hline Biotin & 0.59 & 0.45 & 0.44 & 0.42 & $0.15-1$ \\
\hline Folic acid. & 3.8 & 31 & 26 & 28 & 1.0 \\
\hline Niacin & 156 & 246 & 932 & 384 & $10-28$ \\
\hline Pantothen & $7 \frac{\pi}{2}$ & 77 & 67 & 60 & $10-50$ \\
\hline Vitamin B6 & 868 & 27 & 1528 & na & $3-6$ \\
\hline Thiamine & 14 & 308 & 271 & 155 & 1.0 \\
\hline Riboflavin & 20 & 26 & 23 & 13 & $4-7$ \\
\hline Cobalamine & 0.21 & na & na & 0.19 & $0.015-0.053$ \\
\hline Sum vitamin A & 7.9 & 6.0 & 5.6 & 3.9 & 0.8 \\
\hline Vitamin D & 0.10 & na & na & 0.14 & $0.01-0.04$ \\
\hline Vitamin E & na & 511 & 273 & 36 & 50 \\
\hline Menadione bisulfit ${ }^{3}$ & 0.036 & 0.034 & 0.010 & 0.025 & $\mathrm{NT}$ \\
\hline Sum vitamin $\mathrm{K}^{3}$ & 0.14 & 0.12 & 0.13 & 0.11 & NT \\
\hline Astaxanthin & 36 & 57 & 46 & 0 & - \\
\hline
\end{tabular}


C

\begin{tabular}{|c|c|c|c|c|c|}
\hline & 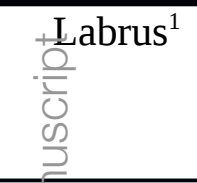 & $\begin{array}{c}\text { Vitalis }^{2} \\
2010\end{array}$ & $\begin{array}{c}\text { Vitalis+shrimp } \\
2010\end{array}$ & $\begin{array}{c}\text { Vitalis+shrimp } \\
2011\end{array}$ & NRC (2011) \\
\hline Macrominerals (g kg-1) & 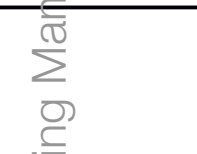 & & & & \\
\hline $\mathrm{Ca}$ & 23 & na & na & 19 & - \\
\hline $\mathrm{Na}$ & $\simeq 16$ & na & na & 10 & - \\
\hline K & 10 & na & na & 8 & - \\
\hline Mg & (d) 3.3 & na & na & 2.0 & $0.4-0.6$ \\
\hline$P$ & 20 & na & na & 13 & 6-8 \\
\hline \multicolumn{6}{|l|}{ Microminerals (mg kg ${ }^{-1}$ ) } \\
\hline $\mathrm{Fe}$ & 0.24 & na & na & 0.32 & $0.03-0.15$ \\
\hline I & 4.4 & na & na & 4.7 & 0.6 \\
\hline $\mathrm{Mn}$ & 30 & 45 & 41 & 37 & $2-12$ \\
\hline $\mathrm{Cu}$ & 21 & 16 & 19 & 24 & 3-5 \\
\hline $\mathrm{Zn}$ & 171 & 197 & 188 & 175 & $15-37$ \\
\hline Se & 1.73 & 2.2 & 2.1 & 1.06 & $0.15-0.25$ \\
\hline
\end{tabular}




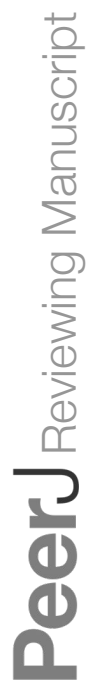


D

\begin{tabular}{|c|c|c|c|c|c|}
\hline \multirow[t]{2}{*}{$\%$ of total FA } & Labrus $^{1}$ & Vitalis $^{2}$ & Vitalis+shrimp & Vitalis+shrimp & $\overline{\text { NRC (2011) }}$ \\
\hline & 을 & 2010 & 2010 & 2011 & \\
\hline Fatty acids (\% TFA) & $\frac{\mathscr{D}}{D}$ & & & & \\
\hline $16: 0$ & 17.6 & 17.2 & 17.2 & 15.4 & - \\
\hline 18:0 & 3.8 & 3.7 & 3.3 & 2 & - \\
\hline $18: 1 n-9$ & 11.0 & 11.0 & 9.5 & 11.7 & - \\
\hline $18: 2 n-6$ & 8.8 & 9.4 & 5.5 & 9 & - \\
\hline 20:4n-6 ARA & (d) 1.2 & 1.1 & 0.6 & 0.6 & - \\
\hline 20:5n-3 EPA & 13.5 & 12.9 & 17.1 & 8.5 & - \\
\hline 22:6n-3 DHA & 12.3 & 12.2 & 8.9 & 10.2 & - \\
\hline DHA:EPA & 0.91 & 0.94 & 0.52 & 1.20 & - \\
\hline ARA:EPA & 0.09 & 0.09 & 0.04 & 0.07 & - \\
\hline
\end{tabular}









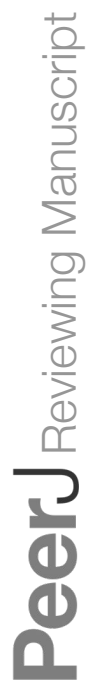




\section{Table 3 (on next page)}

Analytical methods for the different nutrients. 


\begin{tabular}{|c|c|c|}
\hline Analyte & Principle & Reference \\
\hline Dry matter & Gravimetric after freeze drying & Hamre \& Mangor-Jensen 2006 \\
\hline Protein & $\mathrm{N} x$ 6.25, Leco $\mathrm{N}$ analyzer & Hamre \& Mangor-Jensen 2006 \\
\hline Taurine & Total amino acids & Espe et al. 2006 \\
\hline Lipid (tissues) & Gravimetric after ethyl solven extraction & Lie et al. 1988 \\
\hline Lipid (feed) & Gravimetric after acid hydrolysis & EU directive 84/4 1983 \\
\hline Fatty acids & Transmethylation extraction and GC/FID & Lie \& G. 1991 \\
\hline Vitamin C & HPLC & Mæland \& Waagbø 1998 \\
\hline Biotin & Micriobiological & Mæland et al. 2000 \\
\hline Folic acid & Micriobiological & Mæland et al. 2000 \\
\hline Niacin & Micriobiological & Mæland et al. 2000 \\
\hline Pantothenic acid & Micriobiological & Mæland et al. 2000 \\
\hline Vitamin B6 & HPLC & CEN 2003 \\
\hline Thiamine & HPLC & CEN 2003 \\
\hline Riboflavin & HPLC & CEN 2005 \\
\hline Cobalamin & Micriobiological & Mæland et al. 2000 \\
\hline Vitamin A & HPLC & Moren et al. 2002 \\
\hline Vitamin D & HPLC & CEN 1999 \\
\hline Vitamin E & HPLC & Hamre et al. 2010 \\
\hline Sum vitamin $\mathrm{K}^{3}$ & HPLC & CEN 2003 \\
\hline Astaxanthin & HPLC & Ørnsrud et al. 2004 \\
\hline Macrominerals & ICP-MS & Julshamn et al. 2007 \\
\hline Microminerals & ICP-MS & Julshamn et al. 2004 \\
\hline Iodine & ICPMS & Julshamn et al. 2001 \\
\hline
\end{tabular}




\section{Table 4(on next page)}

Models fitted to three component mixture design data investigating the optimum composition of dietary protein (P), lipid (L) and carbohydrate $(\mathrm{CH})$ for Ballan wrasse.

The coefficients for the different terms and the significance of the terms are given for the different models. Cubic models were the basis for the models for length and weight and a quadratic model was used for condition factor. Insignificant terms were removed when appropriate. 


\begin{tabular}{|c|c|c|c|c|c|c|}
\hline & \multicolumn{2}{|c|}{ Weight } & \multicolumn{2}{|c|}{ Length } & \multicolumn{2}{|c|}{ Condition factor } \\
\hline & Coefficient & $P$ term & Coefficient & $P$ term & Coefficient & $P$ term \\
\hline $\mathrm{P}$ & 0.026 & & 0.050 & & 0.023 & \\
\hline $\mathrm{L}$ & 으. 1.31 & 0.0003 & 0.98 & 0.0138 & 0.055 & 0.002 \\
\hline $\mathrm{CH}$ & - 1.26 & & -1.03 & & -0.028 & \\
\hline PxL & $=0.024$ & 0.0002 & -0.017 & 0.019 & -0.00078 & 0.003 \\
\hline $\mathrm{PxCH}$ & สิ).019 & 0.0009 & 0.018 & 0.0397 & 0.00056 & 0.02 \\
\hline $\mathrm{LxCH}$ & 8.0060 & 0.19 & 0.0050 & 0.4281 & & \\
\hline PxLxCH & ס & & & & & \\
\hline $\operatorname{PxLx}(\mathrm{P}-\mathrm{L})$ & 00012 & 0.004 & 0.00011 & 0.0454 & & \\
\hline $\mathrm{PxCHx}(\mathrm{P}-\mathrm{CH})$ & $\frac{3}{2}$ & & $-1.7 \times 10^{-6}$ & 0.169 & & \\
\hline $\mathrm{LxCHx}(\mathrm{L}-\mathrm{CH})$ & 要.00051 & 0.0009 & -0.00027 & 0.0175 & & \\
\hline Adjusted R2 & 0.96 & & 0.84 & & 0.86 & \\
\hline$P$ model & (1). .0004 & & 0.03 & & 0.002 & \\
\hline
\end{tabular}




\section{Table 5(on next page)}

Responses without systematic variation in experiment 1 ; optimal composition of macronutrients for Ballan wrasse. 


\begin{tabular}{|c|c|c|}
\hline$\%$ & Average exp groups & Commercial control \\
\hline Survival & $80 \pm 7$ & 96 \\
\hline HSI & $1.6 \pm 0.2$ & 1.2 \\
\hline \multicolumn{3}{|l|}{ Whole body } \\
\hline Dry matter & $22 \pm 1$ & 23 \\
\hline Protein & $71 \pm 3$ & 69 \\
\hline Lipid & $19 \pm 2$ & 20 \\
\hline Glycogen & $0.58 \pm 0.26$ & 0.83 \\
\hline Ash & $11 \pm 1$ & 10 \\
\hline \multicolumn{3}{|l|}{ Liver } \\
\hline Dry matter & $34 \pm 3$ & 35 \\
\hline Protein & $36 \pm 5$ & 37 \\
\hline Glycogen & $7.7 \pm 3.2$ & 9.7 \\
\hline Total fatty acids & $46 \pm 11$ & 34 \\
\hline
\end{tabular}




\section{Table 6 (on next page)}

Nutrient composition (in dry matter) of whole body of cultured Ballan wrasse juveniles compared to wild caught Ballan wrasse. A. Macronutrient and taurine. B. Vitamins. C. Minerals. D. Fatty acids.

ANOVA analyses is done for data with homogenous variances. Different superscripts indicate significant differences. The Kruskal-Wallis test was performed on all data. Differences were considered significant at $\mathrm{p}<0.05$. ns. not significant. Na. not analysed due to variances not being homogenous. ${ }^{1}$ G. Generation; fish from MHL. Marine Harvest Labrus ${ }^{2}$ The samples were $30-50$ pooled fish per tank ${ }^{3}$ The wild fish were caught in fish traps near Austevoll Aquaculture Research Centre in Western Norway ${ }^{4}$ Labrus feed is an ongrowing diet produced for Ballan wrasse by Skretting AS. Stavanger. Norway. The feed had been fed for 3 months and 4-5 months before sampling. ${ }^{5}$ Vitalis is a broodstock diet produced for marine fish by Skretting AS, Stavanger, Norway. it was blended with shrimp at the rearing facility. The feed had been fed for 4-5 months before sampling. ${ }^{6}$ Sufficient material to analyze one replicate only. 


\begin{tabular}{|c|c|c|c|c|c|c|c|}
\hline $\begin{array}{l}\text { Fish origin }^{1} \\
\text { Feed }\end{array}$ & & $\begin{array}{c}\text { G02-2011 } \\
\text { Labrus }^{4}\end{array}$ & $\begin{array}{c}\text { G01-2011 } \\
\text { Labrus }^{4}\end{array}$ & $\begin{array}{c}\text { G01-02-2010 } \\
\text { Vitalis+shrimp }\end{array}$ & $\begin{array}{c}\text { Wild fish }{ }^{3} \\
-\end{array}$ & $\begin{array}{c}P \\
\text { ANOVA }\end{array}$ & $\begin{array}{c}P \\
\text { Kruskal Wallis }\end{array}$ \\
\hline Dry matter & $\mathrm{g} \cdot \stackrel{\oplus}{\mathrm{P}} 0 \mathrm{~g}^{-1}$ & $19.7 \pm 0.5^{\mathrm{a}}$ & $22.3 \pm 1.1^{\mathrm{ab}}$ & $25.6 \pm 0.3^{b}$ & $26.3 \pm 2.4^{\mathrm{b}}$ & 0.0009 & 0.015 \\
\hline Protein & $\mathrm{g}^{1} 00 \mathrm{~g}^{-1}$ & $75.1 \pm 1.3$ & $73 \pm 1$ & $68 \pm 4$ & $71.1 \pm 3.9$ & ns & ns \\
\hline Taurine & $\mathrm{gg}^{-1}$ & $12.9 \pm 1.2^{\mathrm{a}}$ & $13.2 \pm 1.2^{\mathrm{a}}$ & $7.9 \pm 0.2^{b}$ & $11.4 \pm 0.9^{\mathrm{a}}$ & 0.0001 & 0.019 \\
\hline Lipid & $\mathrm{g}$ & $6.9 \pm 0.4^{\mathrm{a}}$ & $9.4 \pm 1.9^{\mathrm{a}}$ & $22 \pm 1^{\mathrm{b}}$ & $12.8 \pm 5.7^{\mathrm{ab}}$ & 0.002 & ns \\
\hline Glycogen & $\mathrm{g} 100 \mathrm{~g}^{-1}$ & $0.5 \pm 0.1$ & $0.6 \pm 0.1$ & $0.5 \pm 0.1$ & $0.7 \pm 0.3$ & ns & ns \\
\hline & 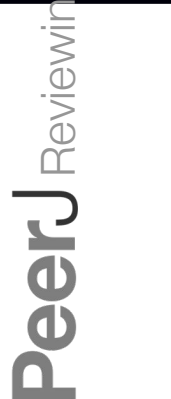 & & & & & & \\
\hline
\end{tabular}




\begin{tabular}{|c|c|c|c|c|c|c|c|}
\hline Fish origin $^{1}$ & & G02-2011 & G01-2011 & G01-02-2010 & Wild fish ${ }^{3}$ & $P$ & $P$ \\
\hline Feed & & Labrus $^{4}$ & Labrus $^{4}$ & Vitalis+shrimp $^{5}$ & - & ANOVA & Kruskal Wallis \\
\hline Vitamin C & $\mathrm{mg} \mathrm{kg}^{-1}$ & $61 \pm 4^{a}$ & $32 \pm 4^{b}$ & $18 \pm 2^{\text {bc }}$ & $9 \pm 6^{c}$ & $<10^{-6}$ & 0.004 \\
\hline Biotin & $\mu \mathrm{N} \mathrm{kg}^{-1}$ & $327 \pm 15^{a}$ & $270 \pm 23^{b}$ & $203 \pm 9^{c}$ & $178 \pm 24^{\mathrm{c}}$ & $<10^{-6}$ & 0.005 \\
\hline Folic acid & $\operatorname{mig}_{\mathrm{g}} \mathrm{kg}^{-1}$ & $1.1 \pm 0.2^{\mathrm{a}}$ & $0.9 \pm 0.1^{\mathrm{ab}}$ & $0.5 \pm 0.0^{\mathrm{bc}}$ & $0.3 \pm 0.1^{\mathrm{c}}$ & $10^{-6}$ & 0.005 \\
\hline Niacin & $\mathrm{mg} \mathrm{kg}^{-1}$ & $64 \pm 7$ & $51 \pm 1$ & $36 \pm 1$ & $47 \pm 6$ & na & 0.01 \\
\hline Pantothenic acid & $\mathrm{mg} \mathrm{kg}^{-1}$ & $20.5 \pm 0.7^{\mathrm{a}}$ & $14.9 \pm 1.0^{\mathrm{b}}$ & $12.1 \pm 0.4^{\mathrm{bc}}$ & $9.9 \pm 1.1^{\mathrm{c}}$ & $<10^{-6}$ & 0.004 \\
\hline Vitamin B6 & $\mathrm{mg} \mathrm{kg}^{-1}$ & $216 \pm 25^{a}$ & $162 \pm 33^{a}$ & $65 \pm 6^{\mathrm{b}}$ & $60 \pm 22^{b}$ & $<10^{-5}$ & 0.008 \\
\hline Thiamine & IIg kg ${ }^{-1}$ & $7.8 \pm 0.6^{a}$ & $5.5 \pm 0.5^{a}$ & $5.1 \pm 0.9^{\mathrm{ab}}$ & $2.6 \pm 1.2^{b}$ & $10^{-4}$ & 0.004 \\
\hline Riboflavin & $11 \mathrm{~kg}^{-1}$ & $9.4 \pm 0.3$ & $9.2 \pm 2.4$ & $7.4 \pm 1.4$ & $4.9 \pm 1.1$ & na & 0.005 \\
\hline Cobalamin & $\mathrm{kg}^{-1}$ & $266 \pm 30^{\mathrm{a}}$ & $213 \pm 29^{\mathrm{ab}}$ & $147 \pm 4^{\text {bc }}$ & $124 \pm 24^{c}$ & $10^{-5}$ & 0.006 \\
\hline Sum vitamin A & $\mathrm{mg} \mathrm{kg}{ }^{-1}$ & $0.9 \pm 0.2^{\mathrm{a}}$ & $1.7 \pm 0.8^{\mathrm{a}}$ & $2.1 \pm 0.1^{\mathrm{ab}}$ & $17 \pm 8^{b}$ & 0.002 & 0.003 \\
\hline Vitamin D & $\mathrm{mg} \mathrm{kg}^{-1}$ & $0.25 \pm 0.09^{\mathrm{a}}$ & $0.11 \pm 0.03^{\mathrm{a}}$ & $0.10 \pm 0.03^{\mathrm{a}}$ & $0.94 \pm 0.19^{b}$ & $<10^{-5}$ & 0.003 \\
\hline Vitamin $E^{6}$ & $\mathrm{mg} \mathrm{kg}^{-1}$ & $45 \pm 13^{a}$ & 65 & $26 \pm 0^{\mathrm{ab}}$ & $18 \pm 10^{b}$ & 0.001 & 0.04 \\
\hline Sum vit K & $\mu g \mathrm{~kg}^{-1}$ & $46 \pm 8$ & $18 \pm 11$ & $13 \pm 0$ & $81 \pm 49$ & na & 0.01 \\
\hline \multicolumn{8}{|l|}{ C } \\
\hline Fish origin $^{1}$ & & G02-2011 & G01-2011 & G01-02-2010 & Wild fish ${ }^{3}$ & $P$ & $P$ \\
\hline Feed & & Labrus $^{4}$ & Labrus $^{4}$ & Vitalis+shrimp $^{5}$ & - & ANOVA & Kruskal Wallis \\
\hline \multicolumn{8}{|c|}{ Macrominerals $\left(\mathrm{g} \mathrm{kg}^{-1}\right)$} \\
\hline $\mathrm{Ca}$ & & $38 \pm 3$ & $43 \pm 1$ & $30 \pm 5$ & $41 \pm 12$ & ns & ns \\
\hline $\mathrm{K}$ & & $15 \pm 1$ & $11 \pm 3$ & $12 \pm 1$ & $11 \pm 1$ & na & 0.04 \\
\hline $\mathrm{Mg}$ & & $2.3 \pm 0.3^{\mathrm{a}}$ & $2.0 \pm 0.2^{\mathrm{ab}}$ & $1.4 \pm 0.0^{c}$ & $1.8 \pm 0.2^{\mathrm{bc}}$ & 0.0002 & 0.01 \\
\hline
\end{tabular}









\begin{tabular}{|c|c|c|c|c|c|c|c|}
\hline $\begin{array}{l}\text { Fish origin }{ }^{1} \\
\text { Feed }\end{array}$ & & G02-2011 & G01-2011 & $\begin{array}{c}\text { G01-02-2010 } \\
\text { Vitalis+shrimn }\end{array}$ & Wild fish ${ }^{3}$ & $\begin{array}{c}P \\
\text { A OVA }\end{array}$ & $\begin{array}{c}P \\
\text { Kruskal Wallis }\end{array}$ \\
\hline $16 \cdot 0$ & & LdDius & $\frac{\text { Ldurus }}{16.3+0.1}$ & $141+01$ & $15+1$ & $\frac{\mathrm{AINUVA}}{\mathrm{ns}}$ & $\frac{\text { ns }}{\text { ns }}$ \\
\hline $18: 1 n-9$ & 능 & $13.4 \pm 0.1$ & $14.0 \pm 0.4$ & $13.2 \pm 0.3$ & $15 \pm 2$ & ns & ns \\
\hline $18: 2 n-6$ & $\begin{array}{l}\bar{D} \\
\infty\end{array}$ & $10.4 \pm 0.2^{\mathrm{b}}$ & $11.9 \pm 0.6^{\mathrm{a}}$ & $6.8 \pm 0.1^{\mathrm{c}}$ & $1.5 \pm 0.2^{\mathrm{d}}$ & $<10^{-2}$ & 0.003 \\
\hline 20:4n-6 ARA & $\stackrel{2}{\beth}$ & $0.6 \pm 0.1$ & $0.5 \pm 0.0$ & $0.7 \pm 0.1$ & $2.4 \pm 0.9$ & na & 0.004 \\
\hline 20:5n-3 EPA & $\sum^{\bar{\sigma}}$ & $8.4 \pm 0.1^{\mathrm{a}}$ & $7.5 \pm 0.4^{\mathrm{a}}$ & $15.1 \pm 0.1^{b}$ & $9.0 \pm 1.1^{\mathrm{a}}$ & $10^{-6}$ & 0.02 \\
\hline 22:6n-3 DHA & 으 & $19.9 \pm 0.5$ & $16.2 \pm 1.9$ & $10.9 \pm 0.0$ & $15.9 \pm 3.1$ & na & 0.03 \\
\hline DHA:EPA & $\cdot \frac{\digamma}{\sum}$ & $2.36 \pm 0.05^{\mathrm{a}}$ & $2.13 \pm 0.16^{\mathrm{a}}$ & $0.72 \pm 0.00^{\mathrm{b}}$ & $1.81 \pm 0.43^{\mathrm{a}}$ & 0.001 & 0.02 \\
\hline ARA:EPA & d) & $0.07 \pm 0.01$ & $0.07 \pm 0.00$ & $0.05 \pm 0.01$ & $0.27 \pm 0.13$ & na & 0.005 \\
\hline
\end{tabular}




\section{Table $7_{\text {(on next page) }}$}

Body weight and length, condition factor (CF), gonadosomatic index (GSI) and hepatosomatic index (HSI) of captive and wild Ballan wrasse females sampled for analyses of nutrient composition of gonad.

Different letters indicate significant differences (t-test, $\mathrm{p}=0.01$ ). 


\begin{tabular}{|c|c|c|c|c|c|}
\hline & Weight & Total Length & & & \\
\hline Fish & (g) & $(\mathrm{cm})$ & $\mathrm{CF}$ & GSI & HSI \\
\hline Captive & $718 \pm 91$ & $35 \pm 1$ & $1.72 \pm 0.13$ & $4.5 \pm 2.5^{\mathrm{a}}$ & $2.08 \pm 0.40$ \\
\hline Wild & $521 \pm 155$ & $31 \pm 3$ & $1.69 \pm 0.29$ & $8.4 \pm 2.3^{b}$ & $1.95 \pm 0.40$ \\
\hline
\end{tabular}




\section{Table $8_{\text {(on next page) }}$}

Nutrient composition (in dry matter) of female gonads from captive and wild Ballan wrasse. A. Macronutrients and taurine. B. Vitamins. C. Minerals. D. Fatty acids.

The captive wrasse had been held at Marine Harvest Labrus for at least one year and fed a moist diet consisting of 75\% Vitalis and 25\% shrimp. Ns; not significant, na; not analysed 
$\underline{\mathrm{A}}$

\begin{tabular}{|c|c|c|c|c|c|}
\hline & & Captive & Wild & $P$ & $P$ \\
\hline $\mathrm{N}$ & & 6 & 10 & t-test & Mw-u test \\
\hline GSI & & $7.0 \pm 1.9$ & $8.7 \pm 2.7$ & ns & ns \\
\hline Dry matter & g $100 \mathrm{~g}^{-1}$ & $20.3 \pm 2.4$ & $21.0 \pm 1.0$ & ns & ns \\
\hline Protein & g $100 \mathrm{~g}^{-1}$ & $76 \pm 0$ & $75 \pm 1$ & ns & ns \\
\hline Taurine & $\mathrm{g} \mathrm{kg}^{-1}$ & $5.6 \pm 1.8$ & $10.4 \pm 1.8$ & 0.002 & 0.014 \\
\hline Total fatty acids & g $100 \mathrm{~g}^{-1}$ & $9.3 \pm 1.4$ & $10.2 \pm 1.4$ & ns & ns \\
\hline
\end{tabular}


B

\begin{tabular}{lcccc}
\hline & Captive & Wild & $P$ & $P$ \\
$\mathrm{~N}$ & 6 & 10 & t-test & Mw-u test \\
\hline Vitamin C & $190 \pm 37$ & $140 \pm 67$ & $\mathrm{~ns}$ & $\mathrm{~ns}$ \\
Biotin & $0.99 \pm 0.29$ & $0.86 \pm 0.11$ & $\mathrm{~ns}$ & $\mathrm{~ns}$ \\
Folic acid & $2.2 \pm 1.0$ & $2.0 \pm 1.0$ & $\mathrm{~ns}$ & $\mathrm{~ns}$ \\
Niacin & $64 \pm 7$ & $49 \pm 7$ & 0.001 & 0.01 \\
Pantothenic acid & $64 \pm 22$ & $43 \pm 7$ & 0.01 & 0.03 \\
Vitamin B6 & $20 \pm 5$ & $12 \pm 1$ & 0.00007 & 0.006 \\
Thiamine & $14 \pm 5$ & $3.7 \pm 1.9$ & 0.00003 & 0.002 \\
Riboflavin & $17 \pm 6$ & $16 \pm 3$ & $\mathrm{~ns}$ & $\mathrm{~ns}$ \\
& & & & \\
Vitamin D & $0.31 \pm 0.23$ & $0.66 \pm 0.33$ & 0.04 & 0.04 \\
Vitamin E & $387 \pm 127$ & $211 \pm 49$ & 0.0007 & 0.002 \\
Vitamin K & na & $0.058 \pm 0.027$ & & \\
Astaxanthin & $0.8 \pm 0.2$ & $0.0 \pm 0.0$ & $\mathrm{~ns}$ & 0.0014 \\
& & & & \\
\hline
\end{tabular}


C

\begin{tabular}{ccccc}
\hline & Captive & Wild & $P$ & $P$ \\
$\mathrm{~N}$ & 6 & 10 & t-test & Mw-u test \\
\hline
\end{tabular}

Macrominerals ( $\left.\mathrm{g} \mathrm{kg}^{-1} \mathrm{DM}\right)$

$\begin{array}{lcccc}\mathrm{Ca} & 0.47 \pm 0.25 & 0.33 \pm 0.05 & \mathrm{~ns} & \text { ns } \\ \mathrm{Na} & 7.9 \pm 2.2 & 6.0 \pm 0.5 & 0.01 & 0.03 \\ \mathrm{~K} & 15.9 \pm 3.5 & 12.8 \pm 1.5 & 0.025 & \mathrm{~ns} \\ \mathrm{Mg} & 0.73 \pm 0.19 & 0.58 \pm 0.11 & \mathrm{~ns} & \mathrm{~ns} \\ \mathrm{P} & 12.8 \pm 1.5 & 11.9 \pm 0.9 & \mathrm{~ns} & \mathrm{~ns}\end{array}$

Microminerals (mg kg-1 DM)

\begin{tabular}{lcccc}
$\mathrm{Fe}$ & $62 \pm 12$ & $43 \pm 9$ & 0.003 & 0.004 \\
$\mathrm{I}$ & $0.61 \pm 0.17$ & $1.48 \pm 0.58$ & 0.003 & 0.004 \\
$\mathrm{Mn}$ & $5.4 \pm 1.5$ & $4.1 \pm 1.0$ & $\mathrm{~ns}$ & 0.03 \\
$\mathrm{Cu}$ & $4.8 \pm 1.4$ & $4.8 \pm 0.8$ & $\mathrm{~ns}$ & $\mathrm{~ns}$ \\
$\mathrm{Zn}$ & $262 \pm 47$ & $169 \pm 24$ & 0.0001 & 0.001 \\
$\mathrm{Se}$ & $2.8 \pm 0.3$ & $3.2 \pm 0.8$ & $\mathrm{~ns}$ & $\mathrm{~ns}$ \\
& & & & \\
\hline
\end{tabular}


D

\begin{tabular}{lcccc}
\hline & Captive & Wild & $P$ & $P$ \\
$\mathrm{~N}$ & 6 & 10 & $\begin{array}{c}P \\
\text { t-test }\end{array}$ & Mw-u test \\
\hline 16:0 & $22 \pm 1$ & $22 \pm 1$ & $\mathrm{~ns}$ & $\mathrm{~ns}$ \\
18:0 & $5 \pm 1$ & $5 \pm 0$ & $\mathrm{~ns}$ & $\mathrm{~ns}$ \\
18:1n-9 & $7 \pm 0$ & $8 \pm 1$ & 0.001 & 0.003 \\
20:4n-6 ARA & $2 \pm 0$ & $6 \pm 2$ & 0.00002 & 0.001 \\
20:5n-3 EPA & $17 \pm 1$ & $12 \pm 1$ & $<10^{-7}$ & 0.001 \\
22:6n-3 DHA & $25 \pm 1$ & $30 \pm 4$ & 0.01 & 0.015 \\
DHA:EPA & $1.5 \pm 0.1$ & $2.5 \pm 0.5$ & 0.0004 & 0.0014 \\
ARA:EPA & $0.10 \pm 0.03$ & $0.49 \pm 0.13$ & $<10^{-5}$ & 0.0014 \\
\hline
\end{tabular}




\section{Figure 1}

Growth responses of Ballan wrasse fed varying dietary levels of macronutrients. A. Final weight. B. Final length. C. Final condition factor.

The triangle represents the response surface for all possible combinations of protein, lipid and carbohydrate and the graded response represents variation in weight, length and condition factor where red is maximum and blue minimum. The red dots represent the composition of the different diets. 

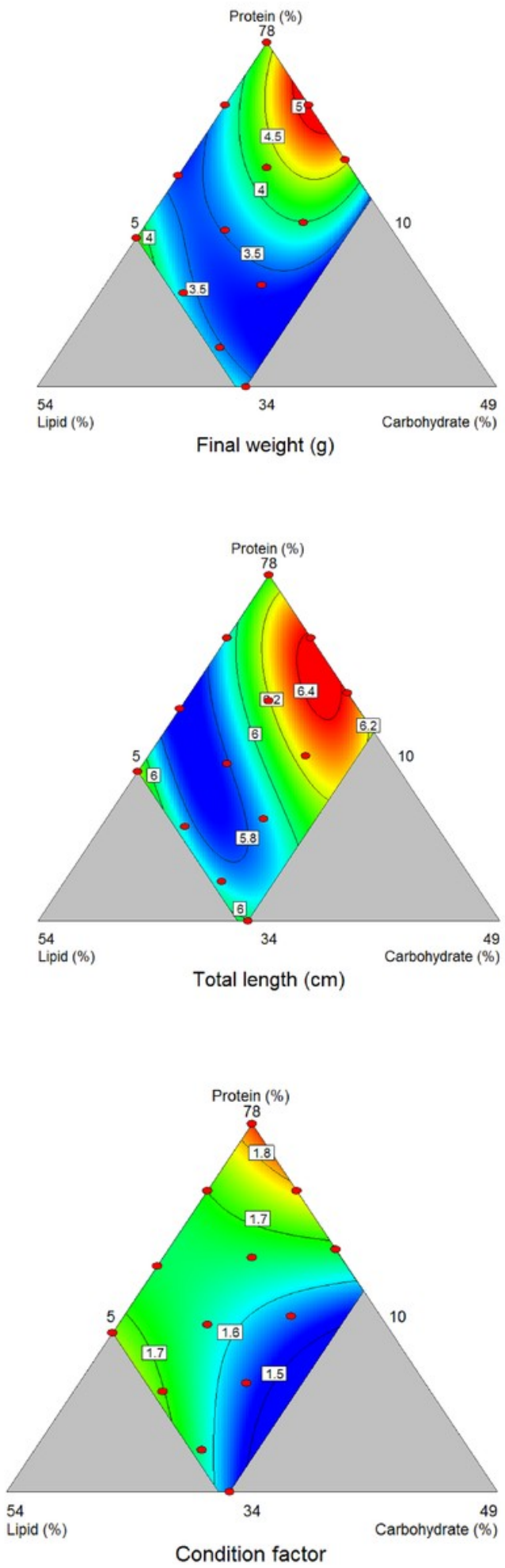


\section{Figure 2}

Variation in nutrient levels with increasing gonadosomatic index (GSI) in broodstock.

Filled squares, captive fish; filled circles, wild fish . 
Dry matter
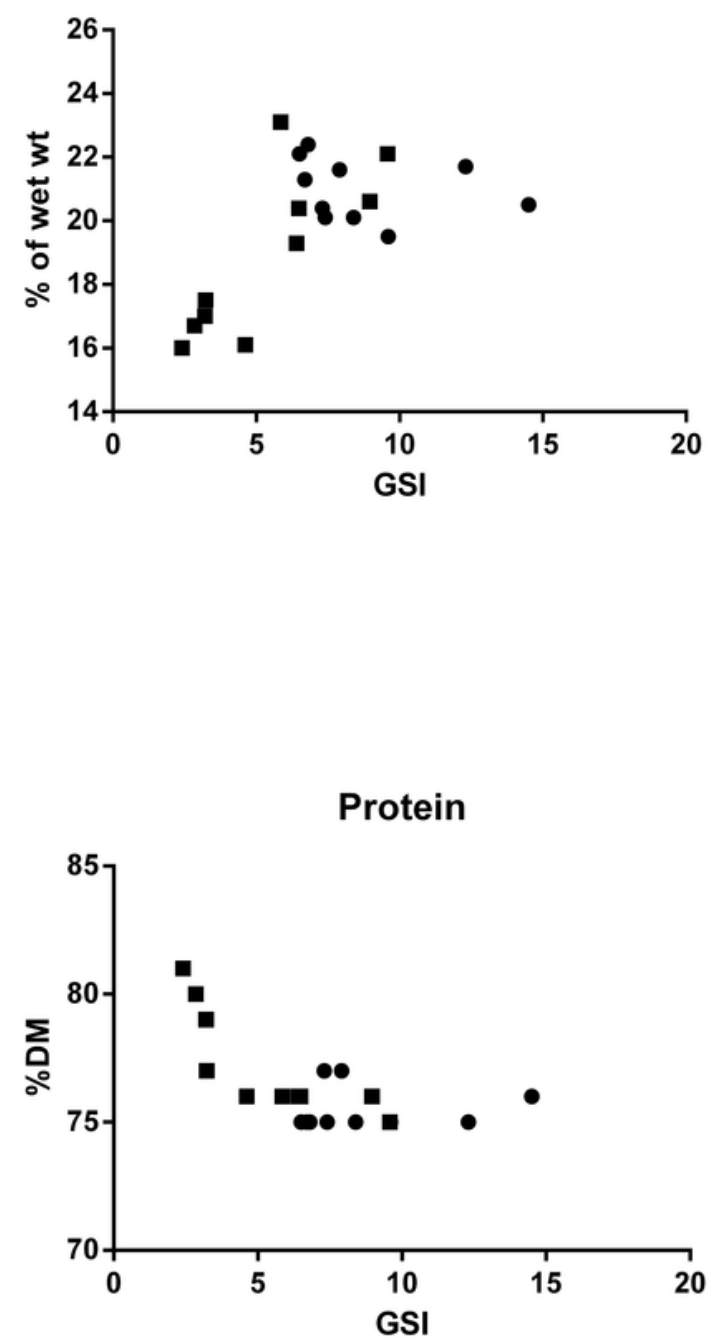

Zinc

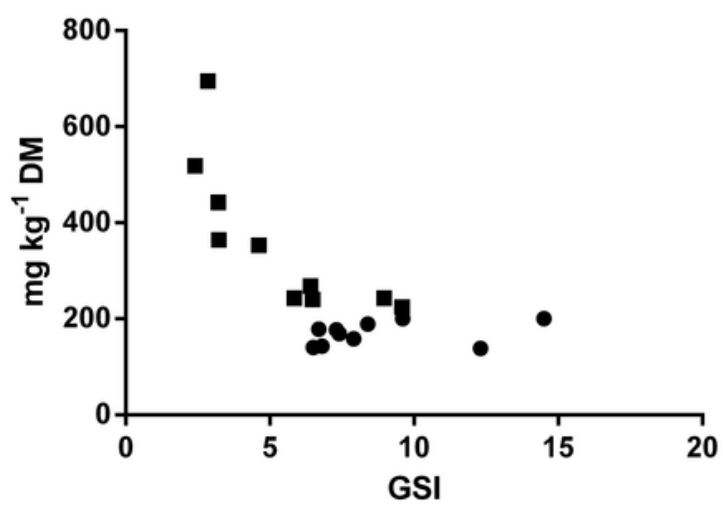

- Wild

- Captive

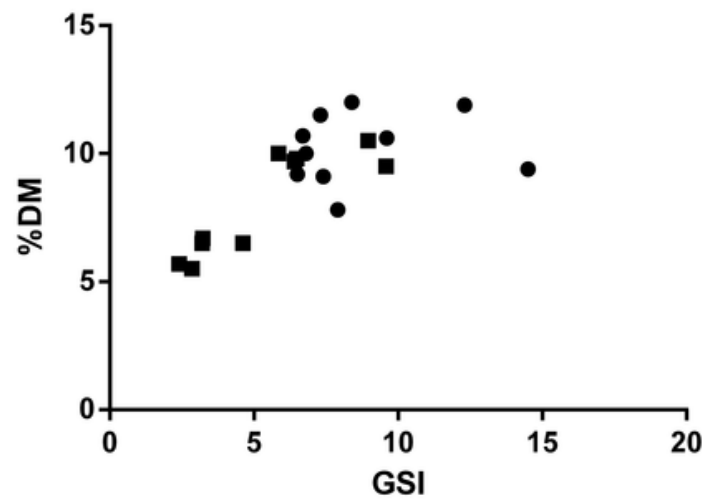

Phosphorus

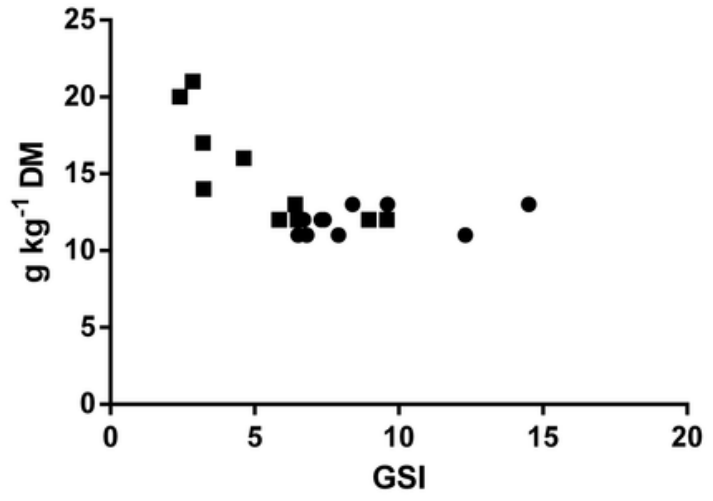

Iron

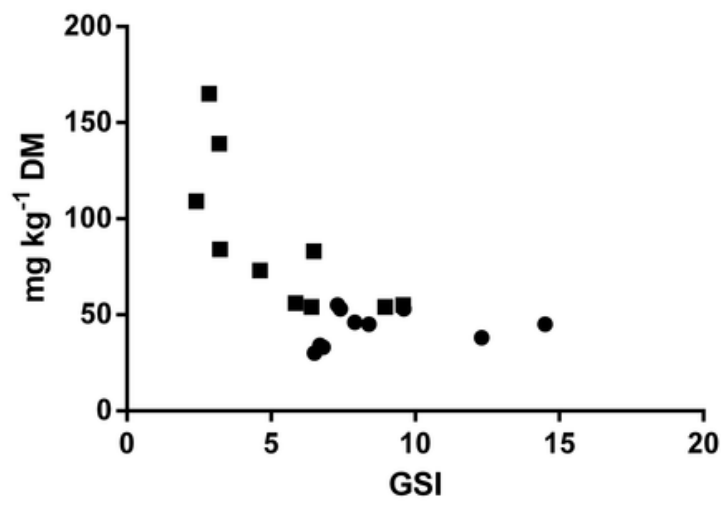

